\title{
Epigenetic regulation in human cancer: the potential role of epi-drug in cancer therapy
}

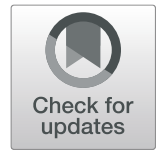

Yuanjun Lu, Yau-Tuen Chan, Hor-Yue Tan, Sha Li, Ning Wang ${ }^{*}$ and Yibin Feng ${ }^{*}$

\begin{abstract}
Epigenetics is dynamic and heritable modifications to the genome that occur independently of DNA sequence. It requires interactions cohesively with various enzymes and other molecular components. Aberrant epigenetic alterations can lead to inappropriate onset of genetic expressions and promote tumorigenesis. As the epigenetic modifiers are susceptible to extrinsic factors and reversible, they are becoming promising targets in multiple cancer therapies. Recently, various epi-drugs have been developed and implicated in clinical use. The use of epi-drugs alone, or in combination with chemotherapy or immunotherapy, has shown compelling outcomes, including augmentation of anti-tumoral effects, overcoming drug resistance, and activation of host immune response.
\end{abstract}

Keywords: Epigenetic modification, Cancer, Epi-drugs, Combination strategy, Tumour microenvironment

\section{Introduction}

The term "epigenetics" was addressed initially as "the branch of biology which studies the causal interactions between genes and their products, which bring the phenotype into being" by C.H. Waddington in the 1940s [1]. From then on, implications of epigenetics have been extended to a wide range of biological processes over time as accumulating evidence suggested that heritable changes to the genome occur independently of alterations in somatic cells regardless of their differentiation status [2]. The heritable changes, either occurring or maintaining during multiple cellular biological processes with the same genetic information, require fine-tuned epigenetic modifications, which commonly including DNA methylation, histone, or chromatin post-translational modifications (PTM), as well as non-coding RNAs regulations. Failure of heritability of epigenetic marks may result in inappropriate initiation or inhibition of gene expressions and lead to pathological changes, including cancers $[3,4]$.

\footnotetext{
*Correspondence: ckwang@hku.hk; yfeng@hku.hk

School of Chinese Medicine, The University of Hong Kong, 10 Sassoon Road, Pofulam 000000, Hong Kong, Special Administrative Region of China
}

Cancer is a consequence of accumulative genetic mutations in concert with epigenetic alterations, as well as environmental factors. A large number of studies have been taking great efforts in characterizing the genomic landscape of cancers from oncogene-driven signalling pathways to the mutation spectrum in different cancer subtypes. Distinct from genetic mutation, epigenetic influences refer to modifying gene expression without permanent changes in the genomic sequence. They are preferentially applied in cancer cells given that epigenetic alterations are reversible and faster regulated compared to genomic evolution [5]. Except for the fundamental changes that occur to the somatic cells, other multiple forces are cohesively shaping the landscape of cancer, thus bringing into additional dimensional complexity. The tumour microenvironment (TME) consists of supporting texture and cells and establishes a niche to fuel tumour cells with a multitude of stromal factors. Current epigenetic modifications are not only focused on the progress of cancer cells development, but also the tumour cells-TME interactions.

Given the importance of epigenetic regulation in cancers, the treatment targeting epigenetics is becoming an attractive strategy of cancer therapy. Epigenetic treatment 
may therefore benefit cancer patients as monotherapy and a combinatory treatment with other current therapy. In this review, we summarize the mechanisms of epigenetic modifications in tumorigenesis, and we also envision more advanced sequencing technologies that would be available for epigenome mapping and enable epigenetic modifications precisely applied in cancer therapy. The drawback and potential pitfall of current epigenetic drugs are also discussed. We hope our review could shed light on the significance of epigenetics in the development and treatment of cancer.

\section{Mechanisms of epigenetic modifications}

The epigenetic modifications can be generally categorized into three groups: DNA and RNA methylations, histone modifications, and non-coding RNAs, which are considered as main mechanisms of regulation during carcinogenesis/cancer progression.

\section{DNA and RNA methylations DNA methylation and demethylation}

DNA methylation is the most extensively studied epigenetic mechanism that predominantly occurs in $\mathrm{CpG}$ islands (CGIs) where preferentially located at the $5^{\prime}$ promoter region of more than $50 \%$ of human genes [6, 7]. It displays a fundamental function in development and diseases, including $\mathrm{X}$ chromosome inactivation, embryonic development, genomic imprinting, epigenetic reprogramming, cell identity establishment, and lineage specification [8-10]. Generally, it exhibits gene silencing via covalent addition of methyl groups from S-adenosylmethionine (SAM) to the 5 position of the cytosine pyrimidine ring. The 5methylcytosine $(\mathrm{m} 5 \mathrm{C})$ structure can either prevent access of transcriptional factors (TFs) to the binding sites of DNA, or recruit methyl-binding domain proteins (MBDs) in association with histone modifications to reconfigure chromatin, thus leading to repressive gene expression.

Three DNA methyltransferases (DNMTs), namely DNMT1, DNMT3a, and DNMT3b, are orchestrated in catalysing DNA methylation. DNMT1, the maintenance DNA methyltransferase, has a higher catalytic activity to preferentially methylate hemimethylated DNA during replication and is mostly responsible for maintaining the DNA methylation status [11, 12]. While the precise DNA methylation status in the genome is generated and supported by "de novo" methyltransferases, DNMT3a and DNMT3b, they display equal preference to bind to the previously unmethylated DNA independently of replication [13].

In contrast, DNA demethylation is a reverse action that recovers silenced genes affected by DNMTs. It is catalysed by a family of Ten-eleven translocation methylcytosine dioxygenases (e.g., TET1, TET2, and TET3), which can turn $5 \mathrm{mC}$ to 5-hydroxymethylcytosine (5-
$\mathrm{hmC}$ ), even further oxidize 5 -hmC into 5-formylcytosine (5-fC) and 5-carboxylcytosine (5-caC) [14, 15]. Homeostasis between the demethylation and methylation of the genome incurs as a dynamic mechanism of gene expression in various types of cells.

\section{RNA methylation}

$\mathrm{N}^{6}$-methyladenosine $\left(\mathrm{m}^{6} \mathrm{~A}\right)$, referring to the methylation of adenosine residue at the N-6 position, was first discovered in the 1970s and is emerging as a hotspot issue in epigenetic mechanisms, as well as in cancer biology. $M^{6} \mathrm{~A}$ modification enriches near the stop codon, 3'UTR, and within internal long exons $[16,17]$. It affects almost every aspect of RNA processing, including RNA transcription, degradation, splicing, and translation [18].

Recent studies have found that $\mathrm{m}^{6} \mathrm{~A}$ modifications are reversible and dynamic. RNA $\mathrm{m}^{6} \mathrm{~A}$ formation requires multiple methyltransferase components categorized as "writers", including methyltransferase-like 3 (METTL3), METTL14, METTL16, Wilms tumour 1-associated protein (WTAP), RNA binding motif protein (RMB15/15B), zinc finger $\mathrm{CCCH}$-type containing 13 (ZC3H13), and KIAA1429 [19-23]. While decoding of $\mathrm{m}^{6} \mathrm{~A}$ methylation can be achieved by interactions among components of "erasers" (e.g. FTO and ALKBH5) and "readers", such as YT521-B homology (YTH) domain-containing proteins, eukaryotic initiation factor 3 (eIF3), heterogenous nuclear ribonucleoprotein (HNRNP) protein family, and insulin-like growth factor 2 mRNA binding proteins (IGF2BP) family [24-27].

\section{Histone modifications}

In chromatin, DNA is packaged into a highly compact structure wrapped with histone octamer, thereby forming nucleosomes and the so-called "beads on a string" structure, which facilitate controlling the accessibility of DNA sequence. Each histone octamer is composed of a tetramer of two copies of histone $2 \mathrm{~A}(\mathrm{H} 2 \mathrm{~A})$ and two copies of histone 2B ( $\mathrm{H} 2 \mathrm{~B})$, flanked by dimers of histone $3(\mathrm{H} 3)$ and histone $4(\mathrm{H} 4)$. These histone proteins contain a globular $\mathrm{C}$-terminal domain and an extended $\mathrm{N}$ terminal tail, which are subject to various PTMs, including methylation, acetylation, ubiquitylation, phosphorylation, SUMOylation, ADP ribosylation, citrullination, and biotinylation at specific amino acidic residues.

Among those PTMs, acetylation, and methylation of lysine residues on $\mathrm{H} 3$ and $\mathrm{H} 4$ have been mostly studied. The mechanism of histone acetylation is based on the "charge neutralization model" that the positive charge of lysine residues on $\mathrm{H} 3 / \mathrm{H} 4$ facilitates a tight packaging of negatively charged DNA with histones. Whereas the addition of an acetyl group can lose up the tight configuration of chromatin, thus enabling transcriptional factors 
(TFs) access for transcription [28]. Multiple enzymes are responsible for catalysing the addition and removal of acetyl groups, including histone acetyltransferases (HATs) and histone deacetylases (HDACs) respectively.

Unlike histone acetylation, the effect of histone methylation is more complicated and dependent on the targeted residues. For example, methylation at lysine 4/36/ 79 of histone $\mathrm{H} 3(\mathrm{H} 3 \mathrm{~K} 4 / 36 / 79)$ typically contributes to active transcriptional status, while methylation at $\mathrm{H} 3 \mathrm{~K} 9 /$ 27 and H4K20 is generally considered to be repressive epigenetic marks [29-32]. They are exclusively catalysed by different histone methyltransferases (HMTs) that most of them contain a SET domain. For example, enhancer of zeste 2 (EZH2) is specific for H3K27 trimethylation (H3K27me3) that exerts transcriptional silencing function [33]. SET7/9 catalyses H3K4me that activates the expression of inflammatory genes [34]. Reversely, removing methyl groups from those marks by histone demethylases (HDMTs) also alters the status of transcriptional activity.

\section{Non-coding RNAs}

Non-coding RNAs (ncRNAs) take up more than 70\% of human genome and have regulatory effects [35]. They are mainly categorized into small ncRNAs (sncRNAs, < $200 \mathrm{nt}$ ) and long ncRNAs (lncRNAs, > $200 \mathrm{nt})$ based on size. The most characterized sncRNA is miRNA, a highly conserved singlestranded RNA with $\sim 20$ nucleotides. They were considered as "junk transcripts" upon their discovery; however they are critical mediators in biological robustness by buffering off the small perturbations, thus ensuring homeostasis of organisms. Almost 60\% of protein-coding genes are subject to miRNAs regulation in humans [36]. They downregulate gene expression via complementarily binding to the 3' UTR of target mRNA. The role of miRNAs, either oncomiRNAs or tumour suppressors, depends on the role of their target genes. More than 50\% of miRNA genes are located closely within CGIs, thereby they are susceptible to other epigenetic modifications [37]. Nowadays, a growing number of studies have revealed the mechanisms of miRNAs in almost all types of cancers.

LncRNAs represent a diverse family of long transcripts generated from different genomic locations. They can influence the target sites either within the nucleus or cytoplasm and play many characters such as chromatin regulators, enhancers, ncRNAs sponge, molecular scaffold, etc. In general regards, lncRNAs are similar with mRNAs that undergo splicing, $5^{\prime}$-cap, and polyadenylation, except newly discovered circular RNAs (circRNAs) which have no cap and poly-A tail [38]. Recent advances have rectified that IncRNAs and circRNAs enable to encode functional peptides with short open reading frames (sORFs), which make their mechanisms more complicated [39].

\section{Aberrant epigenetic changes in cancer development}

\section{Intratumor epigenetic alterations}

Tumorigenesis is a consequence of accumulating changes in genome and epigenome, which confers tumours with traits of heterogeneity and plasticity. Two models have been proposed to decipher how tumours progress: (i) the cancer stem cell (CSC) model, also termed the hierarchical model, regards cancer stem cells as the origin of oncogenic transformation; (ii) the stochastic or clonal evolution model suggests that the initial oncogenic change is acquired progressively by non CSCs $[40,41]$. There is no doubt that epigenetic alterations are critically involved in both models as they can regulate genetic deregulation and certain mutations.

The activation of oncogenes and/or suppression of tumour suppressor genes (TSGs) are considered to be one of factors contributed to the onset of cancer, and they are always consistent with epigenetic changes. DNA methylation acts as a switch controlling the "open" and "off" status of the gene expression (Fig. 1). Hypermethylation of promoters in CGIs is the most recognised mechanism of epigenetic alterations in cancer cells and has been well implicated in various cancer types. Abundant TSGs are under hypermethylation, such as RASSF10 in kidney cancer [42], SIX3 in glioblastoma [43], CDKN2A and PTEN in melanoma $[44,45]$, etc. Besides, not only TSGs hypermethylation is commonly seen in many cancers, but additional genes involved in multiple pivotal cellular functions also present hypermethylation. The studies of prostate cancer (PC) have demonstrated that the heavily methylated situation occurred on the promoters of glutathione S-transferase pi (GSTP1) and other genes such as CDKN2A, TIMPS, and DAPK, which participate in cell cycle, cell metastasis, apoptosis and so forth [46]. By contrast, hypomethylation of oncogenes is commonly reported in multiple cancers, including LY6K in glioblastoma [47], SLC34A2 in papillary thyroid carcinoma [48], RBBP6 in colorectal cancer [49], etc. Moreover, instead of targeting specific genes individually, the variation of DNA methylation is likely to be a genome-wide regulatory scheme. Latest study of genomic and epigenomic landscape in hepatocellular carcinoma (HCC) found that hyper- and hypomethylation occurred in the early preneoplastic phases of HCC, which was significantly relevant to deregulation of cancer-related genes [50].

Apart from aberrant DNA methylation, unbalanced histone modification is abused by those cancers that adhere to the CSC model, in which bidirectional interconversions 


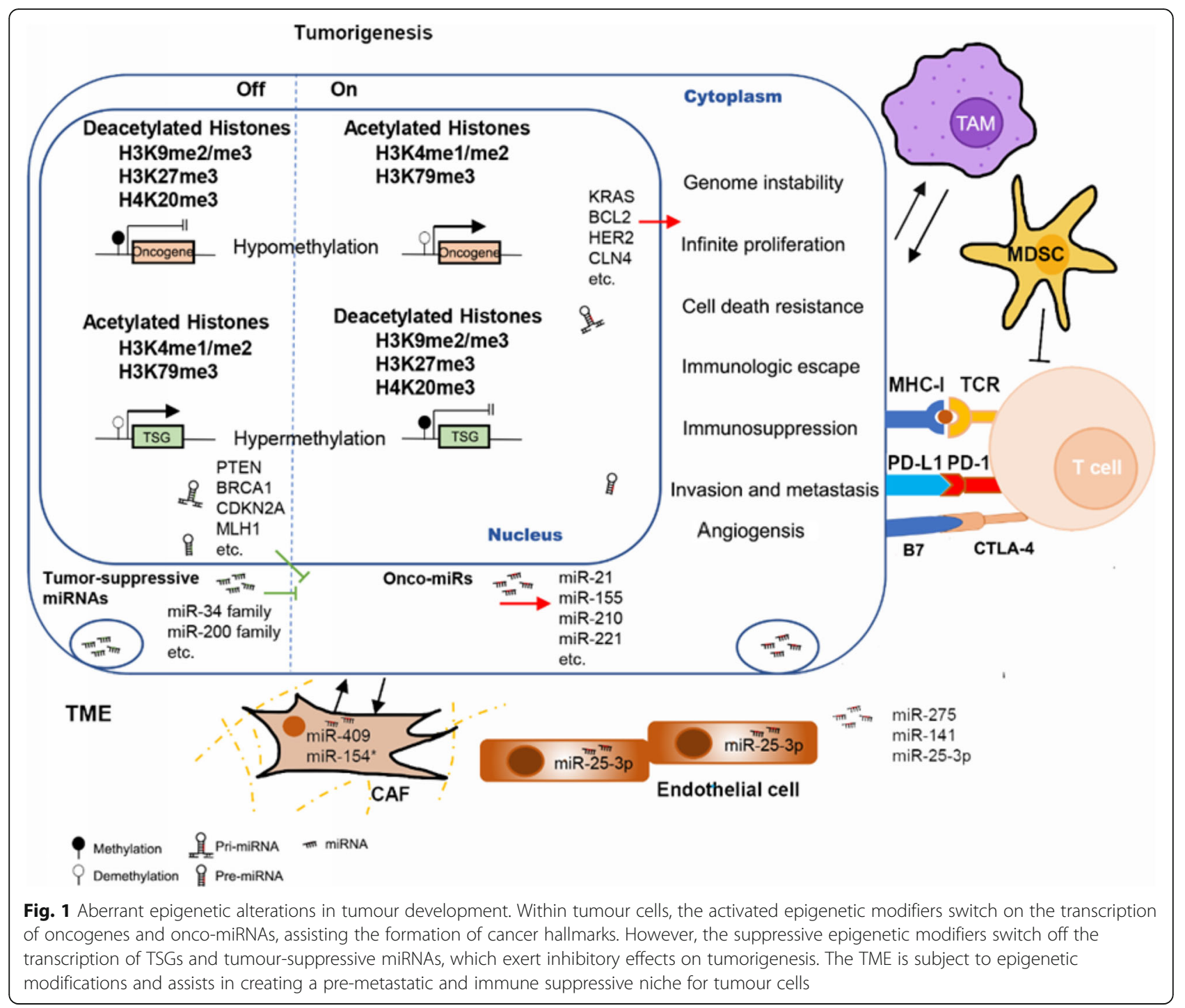

are essential. The bivalent histone marks, activating H3K4me3 and repressive H3K27me3, are originally addressed in the differentiation of embryonic stem cells (ESCs) [51]. However, some types of cancers partially recapitulate this bivalency to deregulate oncofetal genes in cancer cells [52-54]. In colorectal cancer, some genes that supposed to be stem cell markers underwent H3K27me3 loss, such as SOX9, LGR5, ASCL2, OLFM4, EPHB3 [55]. In addition, the bivalency of histone marks on EMTrelated genes (e.g. CDH1, SNAI1, TWIST1) confers them bipotential capacity to potentiate cancer plasticity [56-58].

Aberrant epigenetic alterations on chromosome are dimensionally complex as they are likely to coact during tumorigenesis. Recent studies have demonstrated that histone modifications can be altered along with abnormal DNA methylation or noncoding RNAs. Even one type of histone alteration can affect other histone marks. For example, H3K36me2 expansion caused by NSD2 overexpression in multiple myeloma favored the enrichment of H3K27ac and interactions with other regulatory elements, thus activating oncogenic pathways [59]. Increasing evidence supported that abnormal epigenetic changes may either arise stochastically or be driven by transcriptional program, indicating that the mutations in key elements of epigenetic regulation (e.g. DNMTs, TETs, EZH2, etc.) or specific signalling pathways (e.g. EGFR and KRAS signalling) can modify epigenome [43].

In addition to abnormalities at chromosome level, variations in ncRNAs and RNA modifications are very common in cancer cells. Up to now, tons of aberrant miRNAs are being found in almost every type of cancers. The putative onco-miRNAs (e.g. miR-21, miR-155, miR-210, miR221 , etc.) are usually upregulated in cancer and confer cancer cells advantageous traits by targeting TSGs. By contrast, tumour suppressor miRNAs (e.g. miR-34 family, miR-200 family, etc.) exhibit the opposite function in 
cancers. Of note, some miRNAs serve dual roles, even in a type of cancer. For example, miR-181 family consists of four members miR-181a to miR-181d that exhibit inconsistent expression in many solid cancers, indicating they might be onco-miRNAs as well as tumour suppressor miRNAs [60]. It is intriguing that those members of miR181 family are located at different clusters of chromosomes and subject to different epigenetic modifications, suggesting that miRNA biogenesis can be modified by other epigenetic modifications. Moreover, the interactions among different epigenetic mechanisms can either synergistically or antagonistically alter genetic expression. Another example is that the miR-200 family can target ZEB1 and ZEB2 and inhibit EMT-related genes transcription [61-63]. However, these miRNAs are subject to methylation by DNMT together with the trimethylation of H3K27 and lose control to the EMT phenotype [64-66]. Except the epigenetic effects on miRNAs biogenesis, mature miRNAs can lose their functions by lncRNAs and circRNAs. It has been widely reported that lncRNAs and circRNAs act as miRNA sponge via directly binding to the miRNAs, thus partially abrogating their roles [67]. A latest study in triple-negative breast cancer (TNBC) identified the lncRNA FAM83H-AS1 sequestered miR-136-5p which supposed to inhibit MTDH-induced proliferation, migration, and invasion of TNBC cells [68]. The circRNA circFUT8 was downregulated and proved to be tumour suppressor in bladder cancer through the miR-570-3p/ KLF10 axis [69]. At last but not at least, deregulation of $\mathrm{m}^{6} \mathrm{~A}$ modifications in both pri-miRNA and mRNA processing has been discovered in many cancers. The "writers" METTL3 and METTL14 have been found to be highly abundant in some types of cancers, they exert their oncogenic role by promoting translation of targeted mRNAs through $\mathrm{m}^{6} \mathrm{~A}$ modification [70]. Furthermore, they can alter pri-miRNA processing by recruiting DGCR8 in $\mathrm{m}^{6} \mathrm{~A}$-dependent manner in HCC [71].

\section{Epigenetic alterations in TME}

Recently, the studies on epigenetics have paid more attention to the TME, especially in the regulation of the immune system during tumorigenesis. The TME is comprised of variable materials including stromal cells, immune cells, extracellular matrix and cytokines, creating a favourable and immune-suppressive niche for tumour cells. The changes of TME in both stromal compartments and immune response during tumorigenesis are accompanied with epigenetic reprogramming, especially the aberrant landscape of noncoding RNAs.

Accumulating evidence indicated that there exist a large number of extracellular vesicles (EVs) secreted by many cell types in TME, including exosomes, microvesicles, ectosomes, large oncosomes, exosome-like vesicles, and apoptotic vesicles [72]. They contain DNA fragments, mRNAs and noncoding RNAs and serve as pivotal communicating messengers between cells in early stages of premetastatic niche formation and are critically associated with EMT and metastatic progress [73]. For instance, the exosomal miR-200b was higher in pancreatic ductal adenocarcinoma (PDAC) and indicated shorter overall survival (OS) [74]. It was reported that Non-small cell lung cancer (NSCLC) cell-derived exsomes were overexpressed miR-619-5p that induced cancer cells growth and metastasis by suppressing RCAN1.4 [75]. Moreover, the miRNAs translocated to paracancerous cells can deliver oncogenic signals to shape beneficial TME. In the pre-metastatic niche of colon-rectal cancer (CRC) cells, the exosomal miR-25-3p was transferred to endothelial cells to promote vascular permeability and angiogenesis [76]. The BRACA1-KO fibroblasts that exposed to CRC-derived EVs underwent phenotypical transformation, which was likely caused by cancer DNA, mRNA and miRNAs in EVs [77]. MiR-409 and $\mathrm{miR}-154^{*}$ are found to be expressed in carcinomaassociated fibroblasts (CAFs) which supposed to be silenced after early embryogenesis [78].

It has been widely known that the whole process of tumorigenesis requires an immune-suppressive environment which enables tumour cells to escape from immune surveillance and $\mathrm{T}$ cells-regulated anti-cancer killing. Utilizing the inhibitory immune checkpoint pathway to prevent immune system is one of strategies. The most broadly studied checkpoint proteins are engaged in the surface of both $\mathrm{T}$ cells and cancer cells, generally serving as receptor and ligands, including CTLA-4/CD80 or CD86, PD-1/PD-L1 or PD-L2, LAG3/MHC-II, TIM3/ galectin-9, BTLA/HVEM, TIGIT/CD155 [79, 80]. Induction of those checkpoint proteins can turn T-cells into "off" status, and it is under epigenetic control in cancers. Lower repressive histone marks and DNA methylation marks are usually found at the promoters of checkpoint proteins. It has been reported that PD-1, CTLA-4, TIM-3 and TIGIT were hypomethylated in tumour tissues, compared to the normal tissues, and they also exhibited reduced H3K9me3 and H3K27me3 at their promoters [81, 82]. In addition, ncRNAs are explicitly contribute to epigenetic control in the immune checkpoint that have been summarized in the reference [83].

Except for the role of immune checkpoints in immune suppression, one of the known barriers for deficiency of tumour-infiltrated lymphocytes is the lack of chemokines, including CCL2, CCL4, CXCL8, CXCL9, CXCL10, CXCL12 and CXCL14 etc. These chemokines are supposed to recruit corresponding immune cells into the TME. However, they are epigenetically suppressed in many cancers. For instance, EZH2 was overexpressed to repress the production of T helper 1 (Th1)-type chemokines CXCL9 and CXCL10 via trimethylation at H3K27, 
thus establishing an immune suppressive TME for ovarian cancer [84]. In osteosarcomas, CXCL12 was epigenetically reduced by DNMT1 and lead to impair cytotoxic T-cell homing to the cancer cells [85].

\section{Epigenetics therapy in cancer}

Epigenetic alterations have fundamental functions in cancer progression characterized by reversibility and susceptibility to external factors. They are emerging as promising targets for cancer therapies. The drugs that target the epigenome, called epi-drugs, have been developed more than 40 years. Until now, they have been tested in clinical trials for cancer treatments and displayed favourable outcomes to some extent. A summary of epi-drugs currently in clinical trials can be found in Table 1.

\section{DNMT inhibitors (DNMTIs)}

DNMTIs are potent anticancer therapeutics to reverse the DNA hypermethylation status of TSGs. According to the regulatory mechanisms to the nucleotides, DNMTIs can be divided into two classes: cytosine analogue inhibitors and non-nucleotide analogue inhibitors. In general regards, cytosine analogues can incorporate into the DNA or RNA backbone to replace C-5 of cytosine with $\mathrm{N}-5$ and disturb the methylation, as well as induce DNMTs degradation. They include 5-aza-cytidine (azacytidine), 5-aza-2'-deoxycytidine (decitabine), zebularine, SGI-110, fazarabine, pseudois cytidine, etc.

Azacytidine and decitabine are cytosine analogue inhibitors and have been approved by the FDA for the treatment of hematologic malignancies, specifically myelodysplastic syndrome (MDS) and acute myeloid leukaemia [86, 87]. Nowadays, they are widely implicated in different solid tumours. Azacytidine has a large portion incorporated into RNA, while decitabine is only incorporated into DNA. The action of decitabine starts with DNA integration. After that, the formed azacytosineguanine dinucleotides trap DNMTs with irreversible covalent bindings, thereby exhausting DNMTs and removing the DNA methylation marks on the promoters of TSGs [88]. Furthermore, DNA damage response is triggered along with this process and leads to cell cycle arrest, growth suppression, and apoptosis. As for azacytidine, given to its capacity in the incorporation of RNA, recent studies demonstrated that it can block gene translation via disrupting tRNA-rRNA interactions and inhibit the conversion of deoxyribonucleotides [89]. The anti-tumour activities of these two drugs have been determined in clinical trials at relatively low doses due to their high toxicity caused by high doses.

Apart from azacytidine and decitabine, there are many other cytosine analogues that function in different mechanisms, such as zebularine (ZEB), 6-thioguanine, and 4'-thio-2'-deoxycytidine. ZEB contains a 2-(1H)pyrimidinone ring that leads to degradation of DNMTs via forming a covalent complex with DNMTs at position 6 of the pyrimidinone ring after DNA incorporation [90]. Distinct from azacytidine and decitabine, which can be deactivated by cytidine deaminase (CD), ZEB is more stable with a long half-life that enables oral administration [91]. Of note, ZEB has a preferential response to tumour cells because of faster DNA incorporation and higher response [92, 93]. Although ZEB alone is not as efficient as azacytidine or decitabine due to the competitive effect of cytidine deaminase, it facilitates preventing re-methylation of the gene after treatment of other DNMTIs and may lower doses of DNMTIs [94]. For example, p16 expression may occur re-silence by DNA methylation after decitabine treatment in bladder cancer cells. However, with the addition of ZEB administration, the demethylation effect could be maintained [84]. Therefore, it also combines with azacytidine and decitabine and displays much safer in various cancer treatments, such as AML and EBV-positive Burkitt's lymphoma [95].

In a class of non-nucleotide analogue inhibitors, they are small molecules that prevent the binding of DNMTs to the target sequences either by binding to the catalytic site of DNMTs or binding to the CpG-rich sequences. They include hydralazine, EGCG, RG108, MG98, and disulfiram, etc. Those epi-drugs have slightly inhibitory effects to multiple cancer cells compared with those cytosine analogue inhibitors. MG98 is an antisense oligonucleotide that targets 3'UTR of DNMT1 and induces demethylation in vitro and in vivo [96]. The significant inhibition of DNMT1 expression was observed in phase I clinical study. However, no detectable effect was noted in phase II clinical trial in patients who suffered metastatic renal carcinoma.

\section{HDAC inhibitors (HDACls)}

HDACIs are capable of rectifying the aberrant acetylation status of histones and non-histone proteins in cancers via reactivation of TSGs. Also, cancer cells exhibit a higher sensitivity in response to HDACIs-induced apoptosis. Those features make them become a promising target in cancer therapy. Based on their structure, HDACIs can be divided into four groups: hydroxamic acids, cyclic peptides, aliphatic fatty acids, and benzamides.

The hydroxamic acid HDACIs contain a hydroxamic acid moiety that can bind to the zinc atom, a component in the catalytic sites of HDACs, thus inactivating HDACs. Multiple studies have demonstrated their success in treating both hematologic malignancies and other solid tumours. Currently, three general hydroxamic acid HDACIs have been approved by FDA: (i) Vorinostat (SAHA) which is responsible for cutaneous $\mathrm{T}$-cell 
Table 1 Epi-drugs currently in clinical trial

\begin{tabular}{|c|c|c|c|c|c|}
\hline Target & Drug & Therapeutic Strategy & Cancer/Disease & Phase & $\begin{array}{l}\text { Reference/ } \\
\text { NCT no. }\end{array}$ \\
\hline \multirow[t]{12}{*}{$\overline{\mathrm{DNMT}}$} & \multirow[t]{2}{*}{ Azacytidine $\left(V_{i d a z a}{ }^{\oplus}\right)$} & Monotherapy & MDS, AML & $\begin{array}{l}\text { FDA } \\
\text { approved }\end{array}$ & {$[86]$} \\
\hline & & Polytherapy (cytarabine) & AML & III & [158] \\
\hline & \multirow[t]{2}{*}{ Decitabine (Dacogen $\left.{ }^{\oplus}\right)$} & Monotherapy & MDS, AML & $\begin{array}{l}\text { FDA } \\
\text { approved }\end{array}$ & [87] \\
\hline & & Polytherapy (Talacotuzumab) & AML & III & [159] \\
\hline & Disulfiram & Polytherapy (Chelated Zinc) & Melanoma & $\|$ & NCT02101008 \\
\hline & EGCG & Polytherapy (Green tea) & PC & $\|$ & NCT00666562 \\
\hline & hydralazine & Polytherapy (magnesium valproate) & Refractory solid tumour & $\|$ & [160] \\
\hline & \multirow[t]{2}{*}{ SGI-110 } & Monotherapy & $\mathrm{HCC}$ & $\|$ & NCT01752933 \\
\hline & & $\begin{array}{l}\text { Polytherapy (Pemetrexed, Cisplatin, } \\
\text { Gefitinib) }\end{array}$ & NSCLC & $\|$ & [161] \\
\hline & 6-thioguanine & $\begin{array}{l}\text { Polytherapy (Dexamethasone, } \\
\text { Cyclophosphamide, Vincristine etc.) }\end{array}$ & Lymphoma & IV & [162] \\
\hline & $\begin{array}{l}\text { 4'-thio-2'- } \\
\text { deoxycytidine (TdCyd) }\end{array}$ & Monotherapy & Solid tumour & I (recruiting) & [163] \\
\hline & MG98 & Monotherapy & Solid tumour & I & [164] \\
\hline \multirow[t]{8}{*}{ HDAC } & \multirow{2}{*}{$\begin{array}{l}\text { Abexinostat (PCl- } \\
\text { 24781) }\end{array}$} & Monotherapy & Lymphoma & $|\&| \mid$ & [165] \\
\hline & & Polytherapy (Doxorubicin) & Sarcoma, lymphoma & $|\&| \mid$ & {$[166]$} \\
\hline & CUDC-101 & Monotherapy & Solid tumour & I & [167] \\
\hline & \multirow[t]{3}{*}{$\begin{array}{l}\text { Belinostat (Beleodaq } \\
\text { /PXD101) }\end{array}$} & Monotherapy & $\begin{array}{l}\text { PTCL; HCC, Burkitt lymphoma, DLBCL, } \\
\text { thymic carcinoma, MDS }\end{array}$ & $\begin{array}{l}\text { FDA } \\
\text { approved; }\end{array}$ & [98] \\
\hline & & & & $\|$ & [168] \\
\hline & & Polytherapy (Paclitaxel, Carboplatin) & $\begin{array}{l}\text { Ovarian cancer, fallopian tube cancer, } \\
\text { bladder cancer }\end{array}$ & $|\&| \mid$ & NCT00421889 \\
\hline & Entinostat (SNDX-275) & $\begin{array}{l}\text { Polytherapy (Entinostat, Exemestane, } \\
\text { Placebo) }\end{array}$ & Breast cancer & $\|$ & [169] \\
\hline & Givinostat (ITF2357) & Monotherapy & Polycythemia vera & $|\&| \mid$ & NCT01901432 \\
\hline \multirow[t]{11}{*}{ HDAC } & $\begin{array}{l}\text { Mocetinostat } \\
\text { (MGCD0103) }\end{array}$ & Polytherapy (Gemcitabine) & Metastatic leiomyosarcoma & $\|$ & NCT02303262 \\
\hline & \multirow[t]{3}{*}{$\begin{array}{l}\text { Panobinostat (LBH- } \\
\text { 589) }\end{array}$} & Monotherapy & $\begin{array}{l}\text { MM; thyroid carcinoma, RCC, breast } \\
\text { cancer, AML }\end{array}$ & $\begin{array}{l}\text { FDA } \\
\text { approved; }\end{array}$ & [99] \\
\hline & & & & $\|$ & [170] \\
\hline & & Polytherapy (Placebo) & Hodgkin's lymphoma, MM & III & {$[171]$} \\
\hline & \multirow[t]{2}{*}{ Pracinostat (SB939) } & Monotherapy & MLD & $\|$ & [172] \\
\hline & & Polytherapy (Ruxolitinib) & MLD & $\|$ & NCT02267278 \\
\hline & \multirow[t]{2}{*}{$\begin{array}{l}\text { Romidepsin } \\
\text { (Depsipeptide/FK228) }\end{array}$} & Monotherapy & CTCL, PTCL & $\begin{array}{l}\text { FDA } \\
\text { approved }\end{array}$ & [101] \\
\hline & & $\begin{array}{l}\text { Polytherapy (Alisertib, Pralatrexate, } \\
\text { Gemcitabine) }\end{array}$ & Relapsed PTCL & III & NCT01482962 \\
\hline & Valproic acid (VPA) & $\begin{array}{l}\text { Polytherapy (Azacytidine, All-trans retinoic } \\
\text { acid) }\end{array}$ & MDS, AML & $\|$ & [173] \\
\hline & \multirow[t]{2}{*}{ Vorinostat (SAHA) } & Monotherapy & $\mathrm{CTCL}$ & $\begin{array}{l}\text { FDA } \\
\text { approved }\end{array}$ & [97] \\
\hline & & Polytherapy (KW-0761) & AML & III & [174] \\
\hline \multirow[t]{2}{*}{ BET } & \multirow[t]{2}{*}{$\begin{array}{l}\text { I-BET762 (GSK525762/ } \\
\text { molibresib) }\end{array}$} & Monotherapy & Neoplasms & $\begin{array}{l}\text { ॥ } \\
\text { (recruiting) }\end{array}$ & NCT01943851 \\
\hline & & Polytherapy (Abiraterone, Enzalutamide, & Solid tumour & I (recruiting) & NCT03150056 \\
\hline
\end{tabular}


Table 1 Epi-drugs currently in clinical trial (Continued)

\begin{tabular}{|c|c|c|c|c|c|}
\hline Target & Drug & Therapeutic Strategy & Cancer/Disease & Phase & $\begin{array}{l}\text { Reference/ } \\
\text { NCT no. }\end{array}$ \\
\hline & OTX-015 (MK-8628) & Monotherapy & AML, DLBCL, ALL, MM & I & [175] \\
\hline & \multirow[t]{2}{*}{ TEN-010 (RO6870810) } & Monotherapy & Advanced solid tumors & I (recruiting) & NCT01987362 \\
\hline & & $\begin{array}{l}\text { Polytherapy (atezolizumab, daratumumab, } \\
\text { venetoclax, rituximab) }\end{array}$ & Advanced MM & I (recruiting) & NCT03292172 \\
\hline & CPI-0610 & Polytherapy (Ruxolitinib) & Myelofibrosis, AML, MDS & $\begin{array}{l}\text { | \& || } \\
\text { (recruiting) }\end{array}$ & NCT02158858 \\
\hline & FT-1101 & Polytherapy (Azacitidine) & AML, non-Hodgkin lymphoma & I & NCT02543879 \\
\hline \multirow[t]{6}{*}{ BET } & ZEN003694 & Polytherapy (Talazoparib) & TNBC & $\begin{array}{l}\text { "I } \\
\text { (recruiting) }\end{array}$ & NCT03901469 \\
\hline & \multirow[t]{2}{*}{ BMS-986158 } & Monotherapy & Lymphoma, brain tumour & I (recruiting) & NCT03936465 \\
\hline & & Polytherapy (Nivolumab) & Advanced tumour & $\begin{array}{l}\text { | \& || } \\
\text { (recruiting) }\end{array}$ & NCT02419417 \\
\hline & ABBV-075 & Polytherapy (Vnenetolaclx) & $\begin{array}{l}\text { Solid tumour and hematologic } \\
\text { malignancies }\end{array}$ & । & NCT02391480 \\
\hline & GS-5829 & Polytherapy (Exemestane, Fulvestrant) & Solid tumour, lymphoma & । & NCT02392611 \\
\hline & PLX51107 & Polytherapy (Azacitidine, BRD4 inhibitor) & $\mathrm{AML}, \mathrm{MDS}$ & I (recruiting) & NCT04022785 \\
\hline \multirow[t]{10}{*}{ ncRNA } & MesomiR-1 (miR-16) & Monotherapy & NSCLC, malignant pleural mesothelioma & । & [176] \\
\hline & Miravirsen (miR-122) & Monotherapy & Hepatitis C & $\|$ & {$[177]$} \\
\hline & MRX34 (miR-34) & Monotherapy & $\begin{array}{l}\text { Primary liver cancer, SCLC, lymphoma, } \\
\text { MM, RCC }\end{array}$ & (terminated) & NCT01829971 \\
\hline & MRG1 10 (anti-miR-92) & Polytherapy (Placebo) & Wound healing & । & NCT03603431 \\
\hline & MRG201 (miR-29) & Polytherapy (Placebo) & Fibrous scar tissue formation & । & NCT02603224 \\
\hline & MRG106 (miR-155) & Polytherapy (Cobomarsen, SAHA) & CTCL, Mycosis fungoides & $\begin{array}{l}\text { "I } \\
\text { (recruiting) }\end{array}$ & NCT03713320 \\
\hline & \multirow[t]{2}{*}{ Patisiran } & Monotherapy & Rare polyneuropathy & $\begin{array}{l}\text { FDA } \\
\text { approved }\end{array}$ & [136] \\
\hline & & Polytherapy (Vutrisiran) & Amyloidosis & $\begin{array}{l}\text { III } \\
\text { (recruiting) }\end{array}$ & NCT03759379 \\
\hline & RG-012 (anti-miR-21) & Monotherapy & Alport syndrome & । & NCT03373786 \\
\hline & TargomiRs (miR-15/17) & Monothearpy & Malignant pleural mesothelioma, NSCLC & I & [176] \\
\hline
\end{tabular}

lymphoma (CTCL) [97]; (ii) Belinostat (PXD101) which is responsible for peripheral T-cell lymphomas (PTCL) [98]; and (iii) Panobinostat (LBH-589) which is responsible for multiple myeloma [99]. SAHA is a nonselective broad-spectrum HDACIs that inducing acetylation of histones. It has been reported to enhance the expression of $\mathrm{p} 21$ by inducing acetylated histone $\mathrm{H} 3$ and H4 in bladder carcinoma and endometrial stromal sarcomas [100]. Also, there are other hydroxamic acid HDACIs similarly displaying inhibitory effects on HDACs either selectively or generally, including resminostat, givinostat, pracinostat, abexinostat, and quisinostat, etc. They have been implicated in phase I or II clinical trials for multiple cancers.

Romidepsin (FK2280) is a member of cyclic peptide HDACIs and has received approval of the FDA in 2009 and 2011 for the treatment of CTCL and PTCL respectively [101]. It undergoes reduction by glutathione and releases a zinc-binding thiol within cells. With this thiol,
FK2280 interacts more explicitly with class I/II HDACs, leading to reactive target genes [102, 103].

Valproic acid (VPA) is an example of aliphatic fatty acid HDACIs and selectively targets class I/II HDACs. It was originally developed for the treatment of epilepsy, and its application was then extended to anti-tumour treatment due to its ability in suppressing the proliferation and stimulating the differentiation of cancer cells. VPA can increase histone $\mathrm{H} 3$ and $\mathrm{H} 4$ acetylation and cause demethylation of target genes, especially in nondividing cells. Some of the genes activated by VPA are associated with cancer metastasis (e.g., MMPs) or tumourspecific antigens (e.g., MAGEB2) [104]. Moreover, VPA has a property of low toxicity, well tolerance, and stability, which makes it a promising epi-drug. Phenylbutyrate, AR-42, and pivanex (AN-9) are other members of shortchain fatty acid HDACIs.

Benzamide derivative was firstly reported by Suzuki et al. in the 1990s and displaying significant HDACs 
inhibition [105]. Entinostat (MS-275) and tacedinaline (CI-994) are very active HDACIs of the benzamide group. They possess a 2'-aminophenyl group that binds to the specific site of class I HDACs and display inhibitory effect on HDACs. The treatment of MS-275 could induce expression of multiple genes and increased the overall acetylation status of histones in vitro and in vivo [106]. It was also well-tolerated for patients with lymphoid malignancies and solid tumours in phase I and II clinical trials. Similarly, CI-994 has been tested in phase II clinical trials and could be used alone or in combination with other chemotherapeutic drugs to treat solid tumours in patients $[107,108]$.

\section{Bromodomain and extra terminal inhibitors (BETIs)}

The BET is a family of proteins that contain two Nterminal tandem bromodomains and a C-terminal extra terminal motif, including BRD2, BRD3, BRD4, and BRDT. They form a complex in association with HDACs and other proteins to stimulate transcriptional activity. BRD4 is the most characterized BETs which is exceptionally involved in transcriptional regulation and cancer progression due to its capacity of assembling on both hyper-acetylated gene promoters and "super-enhancers" to promote RNA-polII-mediated transcriptional initiation and elongation $[109,110]$. Several oncogenes have been described as the effectors of BRD4, including cMyc, FOSL1, RUNX2, BCL-2, and c-KIT [111-114]. The efficacy of BETIs is based on the disruption of BETsacetylated histones interaction. So far, several BETIs have encouraging clinical outcomes with tolerable toxicity and potent efficacy, including thienodiazepine JQ1, I-BET762 (GSK525762), I-BET151 (GSK1210151A), GS5829, CPI-0610, TEN-010, OTX-015, and ZEN003694.

JQ1 has been reported to block the interactions of BRD2/3/4 and acetylated histones selectively. One of the target genes c-Myc is subject to downregulation by JQ1 in many different cancers [115]. Furthermore, it exhibits a drastically anti-tumour activity even in castrationresistant cells by disrupting BRD4-mediated androgen receptor (AR) recruitment and transactivation. Recent studies have reported that JQ1 also increased cytotoxic $\mathrm{T}$-cell response by increasing PD-L1 expression [116]. A new oral derivative of JQ1, OTX015, has been synthesized to function as an inhibitor of BRD2/3/4 [117]. Administration of OTX015 could diminish the phenotype of CSCs, providing a compelling strategy in the most aggressive PC [118].

\section{Histone methyltransferases/demethylases inhibitors}

$\mathrm{EZH} 2$ is a histone methyltransferase and is responsible for the catalytic activity of PRC2. EZH2/PRC2 methylates H3K27 and leads to transcriptional silence of target genes in multiple subtypes of cancers, including ovarian cancer, breast cancer, PC, T-cell ALL and non-Hodgkin lymphoma [119-128]. Small molecule EZH2 inhibitors, such as EPZ-6438 (tazemetostat), GSK2816126, and CPI-1205, have been evaluated in clinical trials and showed antineoplastic effects in both hematologic malignancies and various solid tumours. EPZ-6438 is an orally bioavailable EZH2 inhibitor by competing with SAM, which is a cofactor of EZH2 [128]. With encouraging phase I and II clinical trials, EPZ-6438 has been granted as a Fast Track designation for diffuse large B cell lymphoma (DLBCL) and follicular lymphoma (FL), as well as Orphan Drug designation for malignant rhabdoid tumours by FDA [129].

Another group of epigenetic drug precursor is histone demethylase inhibitor, including inhibitors of LSD1 and Jumonji (JmjC). The effect of LSD1 inhibitors is based on the impairment of the H3K4 demethylation [130]. LSD1 inhibitors have been grouped into four classes: (i) reversible poly- or monopeptide inhibitors, (ii) irreversible derivatives of monoamine oxidase inhibitors, (iii) rationally designed fusions of active molecules, and (iv) novel compounds not known to inhibit monoamine oxidase (MAOI). For example, the highly selective LSD1 inhibitors, such as namoline, HCI-2509, NCL-1, have been identified to be reversible inhibitors that have the robust capability of impairing H3K4 demethylation. The treatment of these LSD1 inhibitors can lead to androgenindependent growth arrest without apparent adverse effects in castration-resistant PC cells both in vitro and in vivo [131-133]. The inhibitors of JmjC, which include hydroxamate derivatives, pyridine dicarboxylates, $\mathrm{N}$ oxalyl amino acid derivatives, and agents that interfere with metal binding, have been designed by targeting the 2-OG of the JmjC family, which is a key component for demethylation of methylated lysine $[134,135]$.

\section{NcRNAs}

Increasing studies have shown that miRNAs become biomarkers of multiple cancers as their abnormal levels may be considered to indicate the stage of pathology and prognosis. The applications of miRNAs analogue or antimiRNAs have shown compelling outcomes in-vitro and in-vivo cancer studies, suggesting the miRNA-based drugs are emerging as a novel strategy for cancer therapy. Nowadays, the first small-interfering RNA (siRNA), patisiran, has got approval from the FDA in 2018 for the treatment of rare polyneuropathy via targeting and degrading the mRNA transcription of transthyretin [136]. Many other miRNA-based drugs are under clinical trials and may be translated into FDA-approved drugs in the future, including liposome-formulated miR-34a mimic (MRX34), MRG110, MRG-201, MRG-106, RG-012, RGLS5579, and TargomiRs (miR-15/17 consensus sequences). They either function as miRNA mimics or miRNA antagonists in the 
treatments of different cancers. For example, the expression of tumour suppressor miRNA-34a is usually relatively low in various cancers, such as PC, NSCLC, and ALL, and it has been identified as a tumour suppressor with multiple targets, including CD44, PD-L1, ZEB1, and BCL-2. MRX34 has been developed as a novel strategy to increase the miR-34a level for cancer therapy and has been launched a phase II clinical trial [137]. In terms of higher expression of onco-miRNAs in specific malignancies, the antagomiR-mediated inhibition of specific miRNAs is highly recommended in clinical trials. A latest study has shown that antagomiR-214 decreased disease severity in CTCL, which provides another angle of view for CTCL therapy [138]. Although JQ1 could also downregulate miR-214, indicating the upregulation of miR-214 was caused by aberrant histone acetylation [138].

Numerous lncRNAs are subsequently identified and found to be aberrantly expressed in various tumours. Due to the multifaceted regulations and intricate mechanisms of lncRNAs, few of them have been already implicated as drugs for clinical therapies. However, they are capable of functioning as indicative of the severity of specific cancers as they are supposedly stable in body fluid. For example, the higher lncRNA PCA3 in urine may correspond to the severity of prostate cancer [139]. LncRNA MALAT1, NEAT1, UCA1, and ANRIL can seem as biomarkers for metastatic lung cancers [140]. Similar to the miRNA-mediated strategies, antisensemediated lncRNA targeting is also shown to be a promising tool for some cancer therapies [141]. So far, there are still many hurdles regarding the clinical application of ncRNAs; introducing those ncRNAs with efficient delivery systems is always a potential strategy in cancer therapy.

\section{Epi-drugs combined therapy}

The administration of multiple epi-drugs themselves or in combination with chemotherapy and immunotherapy is becoming a novel approach due to its augmentation of anti-tumoral effects and overcoming drug resistance. The impact of multiple epi-drugs treatments is based on the synergistic actions of epi-drugs. For example, SAHA and panobinostat co-treatment displayed robust anti-cancer activity in colon adenocarcinoma and leukaemia via inducing immunogenic cell death (ICD) [142]. The treatment of SAHA with panobinostat is reported to epigenetically silence the AR gene and repress transcription of the AR targeted genes PSA and tMPRSS2 [143]. The combination of JQ1 or EZH2 inhibitors with panobinostat presents synergistic effects in vitro and in vivo [144, 145].

So far, chemotherapy is still a traditional method for advanced cancers that lack the opportunity for surgical excision. The emergence of chemoresistance becomes a great hindrance to cancer therapy. One of the reasons is that some chemotherapy agents can bring into aberrant epigenetic changes after treatment. For example, cisplatin treatment in ovarian cancer can induce hypermethylation of multiple genes (e.g., MLH1, MEST, MDK) and lead to the acquired resistance phenotype [146]. The addition of decitabine can abate and even reverse the resistance to cisplatin via re-activating those epigeneticsilenced genes, suggesting that combining epi-drugs with other chemotherapeutic agents can not only remarkably promote potent suppression of tumorigenesis, but also re-sensitize tumour cells to radiotherapy and chemotherapy. The studies of HCC have found HDAC3 and HDAC5 mRNAs were upregulated. Inhibiting those HDACs with LBH-589 could increase acetylation of histone H3 and HSP90 and upregulate CDH1 [147]. The SHELTER studies also investigated that the combination of sorafenib (an FDA approved systemic drug) and resminostat, which is an oral pan-HDACi with predominant activity against HDAC1, 2, and 3, showed a compelling outcome with a 2 -fold increase of overall survival (OS) in a second-line setting of advanced HCC, compared to monotherapy of resminostat [148].

Immune checkpoint inhibitors (ICIs) have been considered as a great breakthrough for the treatment of malignant diseases. PD-1/PD-L1 and CTLA-4 inhibitors are the most promising ICIs that some of them have been approved for certain malignancies therapies. However, the clinical benefit of ICIs is obstructed by the lack of surface markers for antigen presentation, impaired $\mathrm{T}$ cell response, re-educated TME, etc. To some extent, those hinders can be overcome by epigenetic reprogramming. Recent studies have provided evidence that the efficacy of PD-1 antibodies can be potentiated by using the DNMTIs. In breast cancer, the major histocompatibility class-I (MHC-I)-encoding genes were methylated and sustained in silence expression status. The treatment with guadecitabine, one of DNMTIs, could enhance MHC-I expression and increase CD8+ T cell infiltration in TME [149]. Those reactions could further potentiate subsequent responses to PD-1 antibodies. Another example is the effect of decitabine in sensitizing CD8+ T cells to PD-L1 antibodies via disrupting the DNMT3Amediated methylation in exhausted $\mathrm{T}$ cells [150]. The administration of belinostat was reported to induce CTLA-4 inhibition, which was responsible for M1phenotypic tumour-associated macrophages (TAMs), and decrease splenic regulatory $\mathrm{T}$ cells (Tregs) [151]. Many other epi-drugs (e.g. JQ1, LSD1 inhibitors, and EZH2 inhibitor) in combination with anti-PD1 therapy, have been revealed that they can increase anti-tumour immune response via enhancing $\mathrm{T}$-cell persistence in different cancers, such as lung cancer, TNBC, and lymphoma, etc. [116, 152] 


\section{Discussion}

Notwithstanding, compelling evidence has described that implying epi-drugs alone or in combination with other drugs in clinical trials, can improve the anti-tumour efficacy. However the accompanying problems may not be underestimated. Firstly, a considerable number of epigenetic compounds are still ongoing in laboratory investigation. The major challenge for those compounds would be how to translate the efficacy in vitro with nanomolar-scale concentrations into well-tolerated and efficient clinical use. MG98 has been found to efficiently reactivate silenced TSGs via downregulation of DNMT1 in several cancer cell lines at concentrations of 25-76 $\mathrm{nM}$ and presented inhibitory effect on proliferation. However, it did not achieve significant response in clinical trials [153].

The off-target of epi-drugs is another problematic issue. As epigenetic regulation is multifaceted, dynamic, and interdependent, the mechanism behind is not clear. Currently, some commonly used epi-drugs, such as VPA, have been known to generate unwanted epigenetic modifications [154, 155]. A well-established safety profile of those epi-drugs are needed to make ease for their applicability in clinical therapy. Meanwhile, the acquired resistance to some of the epi-drugs is becoming a hurdle. The BETIs resistant AML cells displayed PRC2 suppression, which may recover the BETI-targeted c-Myc expression [156]. The hyperphosphorylation of BRD4 is also promoting BETIs resistance in triple-negative breast cancer (TNBC) [157].

\section{Conclusion and future perspectives}

Epigenetics represents a series of dynamic alterations which is independent of genetic changes. They are critically involved in the onset and development of tumorigenesis by regulating the on and off states of oncogenes and TSGs, as well as TME reengineering. Remarkably, epigenetic modifications feature properties of heritable and reversible regulations, making them a promising target for cancer therapy. Current epi-drugs have been used in different cancer types either in a single treatment or a combined treatment with other anti-cancer agents, showing compelling outcomes in some extent. However, the subsequent shortcomings are needed to be considered.

Since human cancer features properties of heterogeneity and plasticity, the request for a precise and effective personalized therapy using epi-drugs is being brought into concern. The standard anti-cancer therapy for general cancer patients has received very limited prognosis due to individual differences. With the advent of high throughput epigenome mapping technologies, the genome and epigenome map of a specific cell population from the patient are available for drug sensitivity testing and drug screening. In this way, the treatments can be optimized for each patient while having much efficiency and less off-target effects.

\begin{abstract}
Abbreviations
5-caC : 5-carboxylcytosine; 5-fC : 5-formylcytosine; 5-hmC : 5hydroxymethylcytosine; $\mathrm{m} 5 \mathrm{C}$ : 5-methylcytosine; AR : Androgen receptor; BETIs : Bromodomain and Extra Terminal inhibitors; CAFs: Carcinomaassociated fibroblasts; CGls : CPG islands; CDKN2A : Cyclin-dependent kinases inhibitor 2A; CD : Cytidine deaminase; CTLA-4 : Cytotoxic T-lymphocyte associated protein 4; DAPK : Death-associated protein kinase; DLBCL : Diffuse large B cell lymphoma; DNMTs : DNA methyltransferases; DNMTIs : DNMT inhibitors; EZH2 : Enhancer of zeste 2; EMT : Epithelial-mesenchymal transition; elF3 : Eukaryotic initiation factor 3; GSTP1 : Glutathione Stransferase pi; H3K27me3 : H3K27 trimethylation; HDACls: HDAC inhibitors; HCC : Hepatocellular carcinoma; HNRNP : Heterogenous nuclear ribonucleoprotein; $\mathrm{H} 2 \mathrm{~A}$ : Histone 2A; H2B : Histone 2B; $\mathrm{H3}$ : Histone 3; $\mathrm{H} 4$ : Histone 4; HATs : Histone acetyltransferases; HDACs: Histone deacetylases; HDMTs : Histone demethylases; HMTs : Histone methyltransferases; HIF-1a : Hypoxia-induced factors 1a; ICls : Immune checkpoint inhibitors; ICD : Immunogenic cell death; IGF2BP : Insulin-like growth factor 2 mRNA binding proteins; InCRNAs: Long nCRNAs; LAG-3 with galectin-9 : Lymphocyte activating 3; H3K4/79 : Lysine 4/79 of histone H3; MHC-I : Major histocompatibility class-l; MBDs : Methyl-binding domain proteins; METTL3 : Methyltransferase-like 3; MDS : Myelodysplastic syndrome; $\mathrm{m}^{6} \mathrm{~A}: \mathrm{N}^{6}$ methyladenosine methylation; ncRNAs : Non-coding RNAs; OS : Overall survival; PTCL : Peripheral T-cell lymphomas; PTM : Post-translational modifications; PD-1 : Programmed death-ligand 1; PC: Prostate cancer; Tregs : Regulatory T cells; RMB15/15B : RNA binding motif protein; SAM : Sadenosylmethionine; snRNAs : Small ncRNAs; siRNA : Sall-interfering RNA; Th1 : T helper 1; TIM-3 : T-cell immunoglobulin mucin 3; CTCL : T-cell lymphoma; TIMPS : Tissue inhibitors of metalloproteinases; TFs: Transcriptional factors;

TNBC : Triple-negative breast cancer; TME : Tumour microenvironment; TSGs : Tumour suppressors genes; TAMs : Tumour-associated macrophages; VPA : Valproic acid; WTAP : Wilms tumour 1-associated protein; YTH : YT521-B homology; ZEB : Zebularine; ZC3H13 : Zinc finger CCCH-type containing 13
\end{abstract}

\section{Acknowledgements}

Authors would like to thank Mr. Keith Wong, Mr. Alex Shek and Ms. Cindy Lee for their assistance.

\section{Authors' contributions}

Y.F. and N.W. conceived the idea, design the study, drafted the manuscript; Y.L. retrieved and analysed the data, and drafted the manuscript; Y.T.C. analysed the data; H.Y.T and S.L. polished the manuscript. The authors read and approved the final manuscript.

\section{Funding}

This research was partially supported by the Research Council of the University of Hong Kong (project codes: 104004092 and 104004460), Wong's donation (project code: 200006276), a donation from the Gaia Family Trust of New Zealand (project code: 200007008), the Research Grants Committee (RGC) of Hong Kong, HKSAR (Project Codes: 740608, 766211, 17152116 and 17121419), Health and Medical Research Fund (Project code: 15162961 and 16172751), Enhanced new staff start-up fund (Project code: 204610519) and Preemptive retention fund (Project code: 202007002).

Availability of data and materials Not applicable.

Ethics approval and consent to participate Not applicable.

Consent for publication Not applicable.

Competing interests

The authors declare that they have no competing interests. 
Received: 17 November 2019 Accepted: 8 April 2020 Published online: 27 April 2020

\section{References}

1. Waddington C. The evolution of an evolutionist. Edinburgh: Edinburgh Univ. Press; 1975.

2. $\quad$ Bird A. Perceptions of epigenetics. Nature. 2007:447:396.

3. Egger G, Liang G, Aparicio A, Jones PA. Epigenetics in human disease and prospects for epigenetic therapy. Nature. 2004;429:457.

4. Jones PA, Baylin SB. The fundamental role of epigenetic events in cancer. Nat Rev Genet. 2002:3:415.

5. Easwaran H, Tsai H-C, Baylin SB. Cancer epigenetics: tumor heterogeneity, plasticity of stem-like states, and drug resistance. Mol Cell. 2014;54:716-27.

6. Lister R, Pelizzola M, Dowen RH, Hawkins RD, Hon G, Tonti-Filippini J, Nery JR, Lee L, Ye Z, Ngo Q-M. Human DNA methylomes at base resolution show widespread epigenomic differences. Nature. 2009;462:315.

7. Bird AP. CpG-rich islands and the function of DNA methylation. Nature. 1986:321:209.

8. Robertson KD. DNA methylation and human disease. Nat Rev Genet. 2005;6:597.

9. Gopalakrishnan S, Van Emburgh BO, Robertson KD. DNA methylation in development and human disease. Mut Res Fundam Mol Mech Mutagenesis. 2008:647:30-8

10. Jin B, Tao Q, Peng J, Soo HM, Wu W, Ying J, Fields CR, Delmas AL, Liu X, Qiu J. DNA methyltransferase 3B (DNMT3B) mutations in ICF syndrome lead to altered epigenetic modifications and aberrant expression of genes regulating development, neurogenesis and immune function. Hum Mol Genet. 2007;17:690-709.

11. Pradhan S, Talbot D, Sha M, Benner J, Hornstra L, Li E, Jaenisch R, Roberts RJ. Baculovirus-mediated expression and characterization of the full-length murine DNA methyltransferase. Nucleic Acids Res. 1997;25:4666-73.

12. Goyal $R$, Reinhardt $R$, Jeltsch A. Accuracy of DNA methylation pattern preservation by the Dnmt1 methyltransferase. Nucleic Acids Res. 2006;34: $1182-8$

13. Liang G, Chan MF, Tomigahara Y, Tsai YC, Gonzales FA, Li E, Laird PW, Jones PA. Cooperativity between DNA methyltransferases in the maintenance methylation of repetitive elements. Mol Cell Biol. 2002;22:480-91.

14. Scourzic L, Mouly E, Bernard OA. TET proteins and the control of cytosine demethylation in cancer. Genome Med. 2015;7:1-16.

15. Zhao $\mathrm{H}$, Chen $\mathrm{T}$. Tet family of 5-methylcytosine dioxygenases in mammalian development. J Hum Genet. 2013;58:421.

16. Meyer KD, Saletore $Y$, Zumbo $P$, Elemento $O$, Mason $C E$, Jaffrey $S R$ Comprehensive analysis of mRNA methylation reveals enrichment in 3' UTRs and near stop codons. Cell. 2012;149:1635-46.

17. Ke S, Alemu EA, Mertens C, Gantman EC, Fak JJ, Mele A, Haripal B, ZuckerScharff I, Moore MJ, Park CY. A majority of m6A residues are in the last exons, allowing the potential for 3' UTR regulation. Genes Dev. 2015;29:2037-53.

18. Chen $X-Y$, Zhang J, Zhu J-S. The role of $m 6$ a RNA methylation in human cancer. Mol Cancer. 2019:18:103.

19. Schumann U, Shafik A, Preiss T. METTL3 gains R/W access to the epitranscriptome. Mol Cell. 2016;62:323-4.

20. Liu J, Yue Y, Han D, Wang X, Fu Y, Zhang L, Jia G, Yu M, Lu Z, Deng X. A METTL3-METTL14 complex mediates mammalian nuclear RNA N 6adenosine methylation. Nat Chem Biol. 2014;10:93.

21. Ping $X-L$, Sun B-F, Wang $L$, Xiao W, Yang $X$, Wang W-J, Adhikari S, Shi $Y$, LV $Y$, Chen Y-S. Mammalian WTAP is a regulatory subunit of the RNA N6methyladenosine methyltransferase. Cell Res. 2014;24:177.

22. Meyer KD, Jaffrey SR. Rethinking m6A readers, writers, and erasers. Annu Rev Cell Dev Biol. 2017;33:319-42.

23. Schwartz S, Mumbach MR, Jovanovic M, Wang T, Maciag K, Bushkin GG, Mertins P, Ter-Ovanesyan D, Habib N, Cacchiarelli D. Perturbation of m6A writers reveals two distinct classes of mRNA methylation at internal and $5^{\prime}$ sites. Cell Rep. 2014;8:284-96.

24. Jia G, Fu Y, Zhao X, Dai Q, Zheng G, Yang Y, Yi C, Lindahl T, Pan T, Yang YG. N6-methyladenosine in nuclear RNA is a major substrate of the obesityassociated FTO. Nat Chem Biol. 2011;7:885

25. Zheng G, Dahl JA, Niu Y, Fedorcsak P, Huang C-M, Li CJ, Vågbø CB, Shi Y, Wang W-L, Song S-H. ALKBH5 is a mammalian RNA demethylase that impacts RNA metabolism and mouse fertility. Mol Cell. 2013;49:18-29.
26. Haussmann IU, Bodi Z, Sanchez-Moran E, Mongan NP, Archer N, Fray RG, Soller M. m 6 a potentiates Sxl alternative pre-mRNA splicing for robust Drosophila sex determination. Nature. 2016;540:301.

27. Müller S, Glaß M, Singh AK, Haase J, Bley N, Fuchs T, Lederer M, Dahl A, Huang $H$, Chen J. IGF2BP1 promotes SRF-dependent transcription in cancer in a m6A-and miRNA-dependent manner. Nucleic Acids Res. 2018:47:375-90.

28. Offermanns S, Rosenthal W. Encyclopedia of molecular pharmacology. Berlin, Heidelberg: Springer Science \& Business Media; 2008.

29. Wiles ET, Selker EU. H3K27 methylation: a promiscuous repressive chromatin mark. Curr Opin Genet Dev. 2017:43:31-7.

30. Bernstein BE, Mikkelsen TS, Xie X, Kamal M, Huebert DJ, Cuff J, Fry B, Meissner A, Wernig M, Plath K. A bivalent chromatin structure marks key developmental genes in embryonic stem cells. Cell. 2006;125:315-26.

31. Barski A, Cuddapah S, Cui K, Roh T-Y, Schones DE, Wang Z, Wei G, Chepelev I, Zhao K. High-resolution profiling of histone methylations in the human genome. Cell. 2007;129:823-37.

32. Black JC, Van Rechem C, Whetstine JR. Histone lysine methylation dynamics: establishment, regulation, and biological impact. Mol Cell. 2012;48:491-507.

33. Cavalli G. EZH2 Goes Solo. Science. 2012;338:1430-1.

34. Li Y, Reddy MA, Miao F, Shanmugam N, Yee J-K, Hawkins D, Ren B, Natarajan R. Role of the histone H3 lysine 4 methyltransferase, SET7/9, in the regulation of NF-kB-dependent inflammatory genes relevance to diabetes and inflammation. J Biol Chem. 2008;283:26771-81.

35. Djebali S, Davis CA, Merkel A, Dobin A, Lassmann T, Mortazavi A, Tanzer A, Lagarde J, Lin W, Schlesinger F. Landscape of transcription in human cells. Nature. 2012;489:101-8.

36. Friedman RC, Farh KK-H, Burge CB, Bartel DP. Most mammalian mRNAs are conserved targets of microRNAs. Genome Res. 2009:19:92-105.

37. Weber B, Stresemann C, Brueckner B, Lyko F. Methylation of human microRNA genes in normal and neoplastic cells. Cell Cycle. 2007:6:1001-5.

38. Jeck WR, Sharpless NE. Detecting and characterizing circular RNAs. Nat Biotechnol. 2014:32:453.

39. Wu P, Mo Y, Peng M, Tang T, Zhong Y, Deng X, Xiong F, Guo C, Wu X, Li Y. Emerging role of tumor-related functional peptides encoded by IncRNA and circRNA. Mol Cancer. 2020;19:22.

40. Vessoni AT, Filippi-Chiela EC, Lenz G, Batista LFZ. Tumor propagating cells: drivers of tumor plasticity, heterogeneity, and recurrence. Oncogene. 2020; 39:2055-68

41. Chaffer $C L$, Weinberg RA. How does multistep tumorigenesis really proceed? Cancer Discov. 2015:5:22-4.

42. Richter AM, Woods ML, Küster MM, Walesch SK, Braun T, Boettger T, Dammann RH. RASSF10 is frequently epigenetically inactivated in kidney cancer and its knockout promotes neoplasia in cancer prone mice. Oncogene. 2020;39:3114-27.

43. Yu Z, Feng J, Wang W, Deng Z, Zhang Y, Xiao L, Wang Z, Liu C, Liu Q, Chen S. The EGFR-ZNF263 signaling axis silences SIX3 in glioblastoma epigenetically. Oncogene. 2020;39:3163-78.

44. Mirmohammadsadegh A, Marini A, Nambiar S, Hassan M, Tannapfel A, Ruzicka T, Hengge UR. Epigenetic silencing of the PTEN gene in melanoma. Cancer Res. 2006;66:6546-52

45. Marini A, Mirmohammadsadegh A, Nambiar S, Gustrau A, Ruzicka T, Hengge UR. Epigenetic inactivation of tumor suppressor genes in serum of patients with cutaneous melanoma. J Invest Dermatol. 2006:126:422-31.

46. Majumdar S, Buckles E, Estrada J, Koochekpour S. Aberrant DNA methylation and prostate cancer. Curr Genomics. 2011;12:486-505.

47. Sastry NG, Wan $X$, Huang $T$, Alvarez AA, Pangeni RP, Song X, James CD, Horbinski CM, Brennan CW, Nakano I. LY6K promotes glioblastoma Tumorigenicity via CAV-1-mediated ERK1/2 signaling enhancement. Neuro Oncol. 2020.

48. He J, Zhou M, Li X, Gu S, Cao Y, Xing T, Chen W, Chu C, Gu F, Zhou J. SLC34A2 simultaneously promotes papillary thyroid carcinoma growth and invasion through distinct mechanisms. Oncogene. 2020;39:2658-75.

49. Xiao C, Wu G, Zhou Z, Zhang X, Wang Y, Song G, Ding E, Sun X, Zhong L, Li S. RBBP6, a RING finger-domain E3 ubiquitin ligase, induces epithelialmesenchymal transition and promotes metastasis of colorectal cancer. Cell Death Dis. 2019:10:1-17.

50. Ding X, He M, Chan AW, Song QX, Sze SC, Chen H, Man MK, Man K, Chan SL, Lai PB. Genomic and Epigenomic Features of Primary and Recurrent Hepatocellular Carcinomas. Gastroenterology. 2019;157:1630-45 e1636. 
51. Blanco E, González-Ramírez M, Alcaine-Colet A, Aranda S, Di Croce L. The bivalent genome: characterization, structure, and regulation. Trends Genet. 2019;36:118-31.

52. Dhar SS, Lee S-H, Chen K, Zhu G, Oh W, Allton K, Gafni O, Kim YZ, Tomoiga AS, Barton MC. An essential role for UTX in resolution and activation of bivalent promoters. Nucleic Acids Res. 2016;44:3659-74.

53. Zaidi SK, Frietze SE, Gordon JA, Heath JL, Messier T, Hong D, Boyd JR, Kang M, Imbalzano AN, Lian JB. Bivalent epigenetic control of oncofetal gene expression in cancer. Mol Cell Biol. 2017;37:e00352-17.

54. Messier TL, Boyd JR, Gordon JA, Stein JL, Lian JB, Stein GS. Oncofetal epigenetic bivalency in breast cancer cells: H3K4 and H3K27 tri-methylation as a biomarker for phenotypic plasticity. J Cell Physiol. 2016;231:2474-81.

55. Hahn MA, Li AX, Wu X, Yang R, Drew DA, Rosenberg DW, Pfeifer GP. Loss of the polycomb mark from bivalent promoters leads to activation of cancerpromoting genes in colorectal tumors. Cancer Res. 2014;74:3617-29.

56. Cui H, Hu Y, Guo D, Zhang A, Gu Y, Zhang S, Zhao C, Gong P, Shen X, Li Y. DNA methyltransferase $3 \mathrm{~A}$ isoform b contributes to repressing $\mathrm{E}$-cadherin through cooperation of DNA methylation and $\mathrm{H} 3 \mathrm{~K} 27 / \mathrm{H} 3 \mathrm{~K} 9$ methylation in EMT-related metastasis of gastric cancer. Oncogene. 2018;37:4358-71.

57. Sui A, Xu Y, Yang J, Pan B, Wu J, Guo T, Shen Y, Guo X. The histone H3 Lys 27 demethylase KDM6B promotes migration and invasion of glioma cells partly by regulating the expression of SNAI1. Neurochem Int. 2019;124:1239.

58. Malouf GG, Taube JH, Lu Y, Roysarkar T, Panjarian S, Estecio MR, Jelinek J, Yamazaki J, Raynal NJ, Long $\mathrm{H}$. Architecture of epigenetic reprogramming following Twist1-mediated epithelial-mesenchymal transition. Genome Biol. 2013;14:R144.

59. Lhoumaud P, Badri S, Rodriguez-Hernaez J, Sakellaropoulos T, Sethia G, Kloetgen A, Cornwell M, Bhattacharyya S, Ay F, Bonneau R. NSD2 overexpression drives clustered chromatin and transcriptional changes in a subset of insulated domains. Nat Commun. 2019;10:1-18.

60. Rezaei T, Mansoori B, Hashemi ZS, Amini M, Rezaei S, Karami H, Mosafer J, Mokhtarzadeh A, Baradaran B. microRNA-181 serves as a dual-role regulator in the development of human cancers. Free Radic Biol Med. 2019.

61. Hurteau GJ, Carlson JA, Spivack SD, Brock GJ. Overexpression of the microRNA hsa-miR-200c leads to reduced expression of transcription factor 8 and increased expression of E-cadherin. Cancer Res. 2007;67:7972-6.

62. Gregory PA, Bert AG, Paterson EL, Barry SC, Tsykin A, Farshid G, Vadas MA, Khew-Goodall Y, Goodall GJ. The miR-200 family and miR-205 regulate epithelial to mesenchymal transition by targeting ZEB1 and SIP1. Nat Cell Biol. 2008;10:593.

63. Park S-M, Gaur AB, Lengyel E, Peter ME. The miR-200 family determines the epithelial phenotype of cancer cells by targeting the E-cadherin repressors ZEB1 and ZEB2. Genes Dev. 2008;22:894-907.

64. Davalos V, Moutinho C, Villanueva A, Boque R, Silva P, Carneiro F, Esteller M. Dynamic epigenetic regulation of the microRNA-200 family mediates epithelial and mesenchymal transitions in human tumorigenesis. Oncogene. 2012;31:2062.

65. Vrba L, Jensen TJ, Garbe JC, Heimark RL, Cress AE, Dickinson S, Stampfer MR Futscher BW. Role for DNA methylation in the regulation of miR-200c and miR-141 expression in normal and cancer cells. PLoS One. 2010;5:e8697.

66. Wiklund ED, Bramsen JB, Hulf T, Dyrskjøt L, Ramanathan R, Hansen TB, Villadsen SB, Gao S, Ostenfeld MS, Borre M. Coordinated epigenetic repression of the miR-200 family and miR-205 in invasive bladder cancer. Int J Cancer. 2011;128:1327-34.

67. Guil S, Esteller M. RNA-RNA interactions in gene regulation: the coding and noncoding players. Trends Biochem Sci. 2015;40:248-56.

68. Han C, Fu Y, Zeng N, Yin J, Li Q. LncRNA FAM83H-AS1 promotes triplenegative breast cancer progression by regulating the miR-136-5p/ metadherin axis. Aging. 2020;12. https://doi.org/10.18632/aging.102832.

69. He Q, Yan D, Dong W, Bi J, Huang L, Yang M, Huang J, Qin H, Lin T. circRNA circFUT8 upregulates Krüpple-like factor 10 to inhibit the metastasis of bladder Cancer via sponging miR-570-3p. Mol Ther Oncolytics. 2020;16:172-87.

70. Pan Y, Ma P, Liu Y, Li W, Shu Y. Multiple functions of $m 6$ a RNA methylation in cancer. J Hematol Oncol. 2018;11:48.

71. Alarcón CR, Lee H, Goodarzi H, Halberg N, Tavazoie SF. N 6 methyladenosine marks primary microRNAs for processing. Nature. 2015; 519:482-5.

72. Jurj A, Zanoaga O, Braicu C, Lazar V, Tomuleasa C, Irimie A, BerindanNeagoe I. A comprehensive picture of extracellular vesicles and their contents. Molecular Transfer to Cancer Cells. Cancers. 2020;12:298.
73. Ni J, Bucci J, Malouf D, Knox M, Graham P, Li Y. Exosomes in Cancer Radioresistance. Front Oncol. 2019;9:869.

74. Reese M, Flammang I, Yang Z, Dhayat SA. Potential of Exosomal microRNA200b as liquid biopsy marker in pancreatic ductal adenocarcinoma. Cancers. 2020;12:E197.

75. Kim DH, Park S, Kim H, Choi YJ, Kim SY, Sung KJ, Sung YH, Choi C-M, Yun M, Yi Y-S, et al. Tumor-derived exosomal miR-619-5p promotes tumor angiogenesis and metastasis through the inhibition of RCAN1.4. Cancer Lett. 2020:475:2-13.

76. Zeng Z, Li Y, Pan Y, Lan X, Song F, Sun J, Zhou K, Liu X, Ren X, Wang F. Cancer-derived exosomal miR-25-3p promotes pre-metastatic niche formation by inducing vascular permeability and angiogenesis. Nat Commun. 2018:9:5395.

77. Abdouh M, Floris M, Gao Z-H, Arena V, Arena M, Arena GO. Colorectal cancer-derived extracellular vesicles induce transformation of fibroblasts into colon carcinoma cells. J Exp Clin Cancer Res. 2019;38:257.

78. Josson S, Gururajan M, Sung S-Y, Hu P, Shao C, Zhau H, Liu C, Lichterman J, Duan P, Li Q. Stromal fibroblast-derived miR-409 promotes epithelial-tomesenchymal transition and prostate tumorigenesis. Oncogene. 2015;34:2690.

79. Marin-Acevedo JA, Dholaria B, Soyano AE, Knutson KL, Chumsri S, Lou Y. Next generation of immune checkpoint therapy in cancer: new developments and challenges. J Hematol Oncol. 2018;11:39.

80. Zahavi DJ, Weiner LM. Targeting multiple receptors to increase checkpoint blockade efficacy. Int J Mol Sci. 2019;20:158.

81. Sasidharan Nair V, El Salhat H, Taha RZ, John A, Ali BR, Elkord E. DNA methylation and repressive $\mathrm{H} 3 \mathrm{~K} 9$ and $\mathrm{H} 3 \mathrm{~K} 27$ trimethylation in the promoter regions of PD-1, CTLA-4, TIM-3, LAG-3, TIGIT, and PD-L1 genes in human primary breast cancer. Clin Epigenetics. 2018;10:78.

82. Nair VS, Toor SM, Taha RZ, Shaath H, Elkord E. DNA methylation and repressive histones in the promoters of PD-1, CTLA-4, TIM-3, LAG-3, TIGIT, PD-L1, and galectin-9 genes in human colorectal cancer. Clin Epigenetics. 2018;10:104.

83. Smolle MA, Prinz F, Calin GA, Pichler M. Current concepts of non-coding RNA regulation of immune checkpoints in cancer. Mol Asp Med. 2019;70: $117-26$.

84. Peng D, Kryczek I, Nagarsheth N, Zhao L, Wei S, Wang W, Sun Y, Zhao E, Vatan L, Szeliga W. Epigenetic silencing of T H 1-type chemokines shapes tumour immunity and immunotherapy. Nature. 2015;527:249.

85. Li B, Wang Z, Wu H, Xue M, Lin P, Wang S, Lin N, Huang X, Pan W, Liu M, et al. Epigenetic regulation of CXCL12 plays a critical role in mediating tumor progression and the immune response in osteosarcoma. Cancer Res. 2018;78:3938-53.

86. Silverman LR, Demakos EP, Peterson BL, Kornblith AB, Holland JC, OdchimarReissig R, Stone RM, Nelson D, Powell BL, DeCastro CM. Randomized controlled trial of azacitidine in patients with the myelodysplastic syndrome: a study of the cancer and leukemia group B. J Clin Oncol. 2002;20:2429-40.

87. Kantarjian H, Issa JPJ, Rosenfeld CS, Bennett JM, Albitar M, DiPersio J, Klimek $\checkmark$, Slack J, De Castro C, Ravandi F. Decitabine improves patient outcomes in myelodysplastic syndromes: results of a phase III randomized study. Cancer Interdiscip Int J Am Cancer Soc. 2006;106:1794-803.

88. Stresemann C, Lyko F. Modes of action of the DNA methyltransferase inhibitors azacytidine and decitabine. Int J Cancer. 2008;123:8-13.

89. Schaefer M, Hagemann S, Hanna K, Lyko F. Azacytidine inhibits RNA methylation at DNMT2 target sites in human cancer cell lines. Cancer Res. 2009;69:8127-32.

90. Zhou L, Cheng X, Connolly B, Dickman M, Hurd P, Hornby D. Zebularine: a novel DNA methylation inhibitor that forms a covalent complex with DNA methyltransferases. J Mol Biol. 2002;321:591-9.

91. Holleran JL, Parise RA, Joseph E, Eiseman JL, Covey JM, Glaze ER, Lyubimov $A V$, Chen Y-F, D'Argenio DZ, Egorin MJ. Plasma pharmacokinetics, oral bioavailability, and interspecies scaling of the DNA methyltransferase inhibitor, zebularine. Clin Cancer Res. 2005;11:3862-8.

92. Cheng JC, Yoo CB, Weisenberger DJ, Chuang J, Wozniak C, Liang G, Marquez VE, Greer S, Orntoft TF, Thykjaer T. Preferential response of cancer cells to zebularine. Cancer Cell. 2004;6:151-8.

93. Tan W, Zhou W, Yu H-G, Luo H-S, Shen L. The DNA methyltransferase inhibitor zebularine induces mitochondria-mediated apoptosis in gastric cancer cells in vitro and in vivo. Biochem Biophys Res Commun. 2013:430:250-5.

94. Cheng JC, Weisenberger DJ, Gonzales FA, Liang G, Xu G-L, Hu Y-G, Marquez

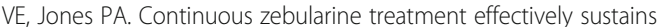
demethylation in human bladder cancer cells. Mol Cell Biol. 2004;24:1270-8. 
95. Takemura Y, Satoh M, Hatanaka K, Kubota S. Zebularine exerts its antiproliferative activity through $\mathrm{S}$ phase delay and cell death in human malignant mesothelioma cells. Biosci Biotechnol Biochem. 2018;82:1159-64.

96. Yang X, Lay F, Han H, Jones PA. Targeting DNA methylation for epigenetic therapy. Trends Pharmacol Sci. 2010;31:536-46.

97. Mann BS, Johnson JR, Cohen MH, Justice R, Pazdur R. FDA approval summary: vorinostat for treatment of advanced primary cutaneous T-cell lymphoma. Oncologist. 2007;12:1247-52.

98. McDermott J, Jimeno A. Belinostat for the treatment of peripheral T-cell lymphomas. Drugs Today (Barcelona, Spain: 1998). 2014;50:337-45.

99. Richardson PG, Laubach JP, Lonial S, Moreau P, Yoon S-S, Hungria VT, Dimopoulos MA, Beksac M, Alsina M, San-Miguel JF. Panobinostat: a novel pan-deacetylase inhibitor for the treatment of relapsed or relapsed and refractory multiple myeloma. Expert Rev Anticancer Ther. 2015;15:737-48.

100. Hrzenjak A, Moinfar F, Kremser M-L, Strohmeier B, Petru E, Zatloukal K, Denk $H$. Histone deacetylase inhibitor vorinostat suppresses the growth of uterine sarcomas in vitro and in vivo. Mol Cancer. 2010;9:49.

101. Frye R, Myers M, Axelrod KC, Ness EA, Piekarz RL, Bates SE, Booher S. Romidepsin: a new drug for the treatment of cutaneous T-cell lymphoma. Clin J Oncol Nurs. 2012;16:195-204.

102. Xiao JJ, Byrd J, Marcucci G, Grever M, Chan KK. Identification of thiols and glutathione conjugates of depsipeptide FK228 (FR901228), a novel histone protein deacetylase inhibitor, in the blood. Rapid Commun Mass Spectrom. 2003;17:757-66.

103. Furumai $R$, Matsuyama $A$, Kobashi $N$, Lee K-H, Nishiyama M, Nakajima $H$, Tanaka A, Komatsu Y, Nishino N, Yoshida M. FK228 (depsipeptide) as a natural prodrug that inhibits class I histone deacetylases. Cancer Res. 2002; 62:4916-21.

104. Milutinovic S, D'Alessio AC, Detich N, Szyf M. Valproate induces widespread epigenetic reprogramming which involves demethylation of specific genes. Carcinogenesis. 2007;28:560-71

105. Kato S, Morie T, Kon T, Yoshida N, Karasawa T, Matsumoto J. Novel benzamides as selective and potent gastrokinetic agents. 2. Synthesis and structure-activity relationships of 4-amino-5-chloro-2-ethoxy-N-[[4-(4fluorobenzyl)-2-morpholinyl] methyl] benzamide citrate (AS-4370) and related compounds. J Med Chem. 1991;34:616-24.

106. Hess-Stumpp H, Bracker TU, Henderson D, Politz O. MS-275, a potent orally available inhibitor of histone deacetylases--the development of an anticancer agent. Int J Biochem Cell Biol. 2007;39:1388-405.

107. Witta SE, Jotte RM, Konduri K, Neubauer MA, Spira Al, Ruxer RL, VarellaGarcia M, Bunn PA Jr, Hirsch FR. Randomized phase II trial of erlotinib with and without entinostat in patients with advanced non-small-cell lung cancer who progressed on prior chemotherapy. J Clin Oncol. 2012;30:2248.

108. Hubeek I, Comijn E, Van der Wilt C, Merriman R, Padron J, Kaspers G, Peters G. Cl-994 (N-acetyl-dinaline) in combination with conventional anti-cancer agents is effective against acute myeloid leukemia in vitro and in vivo. Oncol Rep. 2008;19:1517-23.

109. Donati B, Lorenzini E, Ciarrocchi A. BRD4 and Cancer: going beyond transcriptional regulation. Mol Cancer. 2018;17:164.

110. Lovén J, Hoke HA, Lin CY, Lau A, Orlando DA, Vakoc CR, Bradner JE, Lee TI, Young RA. Selective inhibition of tumor oncogenes by disruption of superenhancers. Cell. 2013;153:320-34.

111. Lockwood WW, Zejnullahu K, Bradner JE, Varmus H. Sensitivity of human lung adenocarcinoma cell lines to targeted inhibition of BET epigenetic signaling proteins. Proc Natl Acad Sci. 2012;109:19408-13.

112. Wyce A, Ganji G, Smitheman KN, Chung C-W, Korenchuk S, Bai Y, Barbash O, Le $B$, Craggs PD, McCabe MT. BET inhibition silences expression of MYCN and BCL2 and induces cytotoxicity in neuroblastoma tumor models. PLOS One. 2013;8:e72967.

113. Sancisi V, Manzotti G, Gugnoni M, Rossi T, Gandolfi G, Gobbi G, Torricelli F, Catellani F, Faria do Valle I, Remondini D. RUNX2 expression in thyroid and breast cancer requires the cooperation of three non-redundant enhancers under the control of BRD4 and c-JUN. Nucleic Acids Res. 2017;45:11249-67.

114. Zhao Y, Liu Q, Acharya P, Stengel KR, Sheng Q, Zhou X, Kwak H, Fischer MA, Bradner JE, Strickland SA. High-resolution mapping of RNA polymerases identifies mechanisms of sensitivity and resistance to BET inhibitors in $\mathrm{t}$ (8; 21) AML. Cell Rep. 2016;16:2003-16

115. Ott CJ, Kopp N, Bird L, Paranal RM, Qi J, Bowman T, Rodig SJ, Kung AL, Bradner JE, Weinstock DM. BET bromodomain inhibition targets both cMyc and IL7R in high-risk acute lymphoblastic leukemia. Blood. 2012; 120:2843-52.
116. Zhu H, Bengsch F, Svoronos N, Rutkowski MR, Bitler BG, Allegrezza MJ, Yokoyama Y, Kossenkov AV, Bradner JE, Conejo-Garcia JR. BET bromodomain inhibition promotes anti-tumor immunity by suppressing PD-L1 expression. Cell Rep. 2016;16:2829-37.

117. Vázquez R, Riveiro ME, Astorgues-Xerri L, Odore E, Rezai K, Erba E, Panini N, Rinaldi A, Kwee I, Beltrame L. The bromodomain inhibitor OTX015 (MK8628) exerts anti-tumor activity in triple-negative breast cancer models as single agent and in combination with everolimus. Oncotarget. 2017;8:7598.

118. Civenni G, Pedrani S, Allegrini S, Bruccoleri A, Albino D, Pinton S, GarciaEscudero R, Ouafik LH, Cvitkovic E, Carbone GM. Targeting prostate cancer stem cells (CSCs) with the novel BET bromodomain (BRD) protein inhibitor OTX015. Philadelphia: AACR; 2015.

119. Shen X, Liu Y, Hsu Y-J, Fujiwara Y, Kim J, Mao X, Yuan G-C, Orkin SH. EZH1 mediates methylation on histone $\mathrm{H} 3$ lysine 27 and complements $E Z H 2$ in maintaining stem cell identity and executing pluripotency. Mol Cell. 2008; 32:491-502

120. Velichutina I, Shaknovich R, Geng H, Johnson NA, Gascoyne RD, Melnick AM, Elemento O. EZH2-mediated epigenetic silencing in germinal center B cells contributes to proliferation and lymphomagenesis. Blood. 2010;116:5247-55

121. Chase A, Cross NC. Aberrations of EZH2 in cancer. Clin Cancer Res. 2011;17: 2613-8.

122. Mahmoudi T, Verrijzer CP. Chromatin silencing and activation by Polycomb and trithorax group proteins. Oncogene. 2001;20:3055.

123. Cao R, Wang L, Wang H, Xia L, Erdjument-Bromage H, Tempst $P$, Jones RS, Zhang Y. Role of histone H3 lysine 27 methylation in Polycomb-group silencing. Science. 2002;298:1039-43.

124. Müller J, Hart CM, Francis NJ, Vargas ML, Sengupta A, Wild B, Miller EL, O'Connor MB, Kingston RE, Simon JA. Histone methyltransferase activity of a Drosophila Polycomb group repressor complex. Cell. 2002;111:197-208.

125. Czermin B, Melfi R, McCabe D, Seitz V, Imhof A, Pirrotta V. Drosophila enhancer of Zeste/ESC complexes have a histone $\mathrm{H} 3$ methyltransferase activity that marks chromosomal Polycomb sites. Cell. 2002;111:185-96.

126. Xu B, Konze KD, Jin J, Wang GG. Targeting EZH2 and PRC2 dependence as novel anticancer therapy. Exp Hematol. 2015;43:698-712.

127. Ntziachristos $P$, Tsirigos A, Van Vlierberghe P, Nedjic J, Trimarchi T, Flaherty MS, Ferres-Marco D, Da Ros V, Tang Z, Siegle J. Genetic inactivation of the polycomb repressive complex 2 in T cell acute lymphoblastic leukemia. Nat Med. 2012;18:298.

128. Knutson SK, Warholic NM, Wigle TJ, Klaus CR, Allain CJ, Raimondi A, Scott MP, Chesworth R, Moyer MP, Copeland RA. Durable tumor regression in genetically altered malignant rhabdoid tumors by inhibition of methyltransferase EZH2. Proc Natl Acad Sci. 2013;110:7922-7.

129. Gulati N, Béguelin W, Giulino-Roth L. Enhancer of zeste homolog $2(E Z H 2)$ inhibitors. Leuk Lymphoma. 2018;59:1574-85.

130. Forneris F, Binda C, Dall'Aglio A, Fraaije MW, Battaglioli E, Mattevi A. A highly specific mechanism of histone $\mathrm{H} 3-\mathrm{K} 4$ recognition by histone demethylase LSD1. J Biol Chem. 2006;281:35289-95.

131. Gupta S, Weston A, Bearrs J, Thode T, Neiss A, Soldi R, Sharma S. Reversible lysine-specific demethylase 1 antagonist $\mathrm{HCl}$-2509 inhibits growth and decreases c-MYC in castration- and docetaxel-resistant prostate cancer cells. Prostate Cancer Prostatic Dis. 2016;19:349-57.

132. Wang M, Liu X, Jiang G, Chen H, Guo J, Weng X. Relationship between LSD1 expression and E-cadherin expression in prostate cancer. Int Urol Nephrol. 2015;47:485-90.

133. Etani T, Suzuki T, Naiki T, Naiki-Ito A, Ando R, lida K, Kawai N, Tozawa K, Miyata N, Kohri K, Takahashi S. NCL1, a highly selective lysine-specific demethylase 1 inhibitor, suppresses prostate cancer without adverse effect. Oncotarget. 2015;6:2865-78.

134. Y-i T, Fang J, Erdjument-Bromage $\mathrm{H}$, Warren ME, Borchers $\mathrm{CH}$, Tempst $\mathrm{P}$, Zhang Y. Histone demethylation by a family of JmjC domain-containing proteins. Nature. 2006:439:811.

135. Klose RJ, Kallin EM, Zhang Y. JmjC-domain-containing proteins and histone demethylation. Nat Rev Genet. 2006;7:715.

136. Wood H. FDA approves patisiran to treat hereditary transthyretin amyloidosis. Nature Reviews Neurology. 2018;14:570.

137. Hanna J, Hossain GS, Kocerha J. The potential for microRNAs in clinical research. Front Genet. 2019;10:478.

138. Kohnken R, McNeil B, Wen J, McConnell K, Grinshpun L, Keiter A, Chen L, William B, Porcu P, Mishra A. Preclinical targeting of MicroRNA-214 in cutaneous T-cell lymphoma. J Invest Dermatol. 2019;139:1966-74. 
139. Lee B, Mazar J, Aftab MN, Qi F, Shelley J, Li J-L, Govindarajan S, Valerio F, Rivera I, Thurn T. Long noncoding RNAs as putative biomarkers for prostate cancer detection. J Mol Diagnostics. 2014;16:615-26.

140. Gutschner T, Hämmerle M, Eißmann M, Hsu J, Kim Y, Hung G, Revenko A, Arun G, Stentrup M, Groß M. The noncoding RNA MALAT1 is a critical regulator of the metastasis phenotype of lung cancer cells. Cancer Res. 2013;73:1180-9.

141. Arun G, Diermeier SD, Spector DL. Therapeutic targeting of long noncoding RNAs in cancer. Trends Mol Med. 2018;24:257-77.

142. West AC, Mattarollo SR, Shortt J, Cluse LA, Christiansen AJ, Smyth MJ, Johnstone RW. An intact immune system is required for the anticancer activities of histone deacetylase inhibitors. Cancer Res. 2013;73:7265-76.

143. Welsbie DS, Xu J, Chen Y, Borsu L, Scher HI, Rosen N, Sawyers CL. Histone deacetylases are required for androgen receptor function in hormonesensitive and castrate-resistant prostate cancer. Cancer Res. 2009;69:958-66.

144. Shahbazi J, Liu PY, Atmadibrata B, Bradner JE, Marshall GM, Lock RB, Liu T. The bromodomain inhibitor JQ1 and the histone deacetylase inhibitor panobinostat synergistically reduce N-Myc expression and induce anticancer effects. Clin Cancer Res. 2016;22:2534-44.

145. Harding T, Swanson J, Van Ness B. EZH2 inhibitors sensitize myeloma cell lines to panobinostat resulting in unique combinatorial transcriptomic changes. Oncotarget. 2018;9:21930.

146. Zeller C, Dai W, Steele NL, Siddiq A, Walley AJ, Wilhelm-Benartzi C, Rizzo S, Van Der Zee A, Plumb J, Brown R. Candidate DNA methylation drivers of acquired cisplatin resistance in ovarian cancer identified by methylome and expression profiling. Oncogene. 2012;31:4567.

147. Lachenmayer A, Toffanin S, Cabellos L, Alsinet C, Hoshida Y, Villanueva A, Minguez B, Tsai H-W, Ward SC, Thung S. Combination therapy for hepatocellular carcinoma: additive preclinical efficacy of the HDAC inhibitor panobinostat with sorafenib. J Hepatol. 2012;56:1343-50.

148. Bitzer M, Horger M, Giannini EG, Ganten TM, Wörns MA, Siveke JT, Dollinger MM, Gerken G, Scheulen ME, Wege H. Resminostat plus sorafenib as second-line therapy of advanced hepatocellular carcinoma-the SHELTER study. J Hepatol. 2016;65:280-8.

149. Luo N, Nixon MJ, Gonzalez-Ericsson PI, Sanchez V, Opalenik SR, Li H, Zahnow CA, Nickels ML, Liu F, Tantawy MN. DNA methyltransferase inhibition upregulates MHC-I to potentiate cytotoxic T lymphocyte responses in breast cancer. Nat Commun. 2018;9:248

150. Ghoneim HE, Fan Y, Moustaki A, Abdelsamed HA, Dash P, Dogra P, Carter R, Awad W, Neale G, Thomas PG. De novo epigenetic programs inhibit PD-1 blockade-mediated T cell rejuvenation. Cell. 2017;170:142-57 e119.

151. Llopiz D, Ruiz M, Villanueva L, Iglesias T, Silva L, Egea J, Lasarte JJ, Pivette P, TrochonJoseph V, Vasseur B. Enhanced anti-tumor efficacy of checkpoint inhibitors in combination with the histone deacetylase inhibitor Belinostat in a murine hepatocellular carcinoma model. Cancer Immunol Immunother. 2019;68:379-93.

152. Sheng W, LaFleur MW, Nguyen TH, Chen S, Chakravarthy A, Conway JR, Li Y, Chen $\mathrm{H}$, Yang H, Hsu P-H. LSD1 ablation stimulates anti-tumor immunity and enables checkpoint blockade. Cell. 2018;174:549-63 e519.

153. Amato RJ. Inhibition of DNA methylation by antisense oligonucleotide MG98 as cancer therapy. Clin Genitourin Cancer. 2007;5:422-6.

154. Finsterer J, Zarrouk Mahjoub S. Mitochondrial toxicity of antiepileptic drugs and their tolerability in mitochondrial disorders. Expert Opin Drug Metab Toxicol. 2012:8:71-9.

155. Chen H, Dzitoyeva S, Manev H. Effect of valproic acid on mitochondrial epigenetics. Eur J Pharmacol. 2012;690:51-9.

156. Rathert $P$, Roth $M$, Neumann $T$, Muerdter F, Roe J-S, Muhar M, Deswal S, Cerny-Reiterer S, Peter B, Jude J. Transcriptional plasticity promotes primary and acquired resistance to BET inhibition. Nature. 2015;525:543.

157. Alqahtani A, Choucair K, Ashraf M, Hammouda DM, Alloghbi A, Khan T, Senzer N, Nemunaitis J. Bromodomain and extra-terminal motif inhibitors: a review of preclinical and clinical advances in cancer therapy. Future Sci OA. 2019:5:FSO372.

158. Seymour JF, Döhner $H$, Butrym A, Wierzbowska A, Selleslag D, Jang JH, Kumar R, Cavenagh J, Schuh AC, Candoni A. Azacitidine improves clinical outcomes in older patients with acute myeloid leukaemia with myelodysplasia-related changes compared with conventional care regimens. BMC Cancer. 2017:17:852.

159. Mayer J, Arthur C, Delaunay J, Mazur G, Thomas XG, Wierzbowska A, Ravandi F, Berrak E, Jones M, Li Y. Multivariate and subgroup analyses of a randomized, multinational, phase 3 trial of decitabine vs treatment choice of supportive care or cytarabine in older patients with newly diagnosed acute myeloid leukemia and poor-or intermediate-risk cytogenetics. BMC Cancer. 2014;14:69.
160. Candelaria M, Gallardo-Rincón D, Arce C, Cetina L, Aguilar-Ponce JL, Arrieta O, Gonzalez-Fierro A, Chavez-Blanco A, de La Cruz-Hernandez E, Camargo $M$. A phase II study of epigenetic therapy with hydralazine and magnesium valproate to overcome chemotherapy resistance in refractory solid tumors. Ann Oncol. 2007;18:1529-38.

161. Ahn M-J, Yang JC-H, Liang J, Kang J-H, Xiu Q, Chen Y-M, Blair JM, Peng G, Linn C, Orlando M. Randomized phase II trial of first-line treatment with pemetrexed-cisplatin, followed sequentially by gefitinib or pemetrexed, in east Asian, never-smoker patients with advanced non-small cell lung cancer. Lung Cancer. 2012;77:346-52.

162. Kobitzsch B, Gökbuget N, Schwartz S, Reinhardt R, Brüggemann M, Viardot A, Wäsch R, Starck M, Thiel E, Hoelzer D. Loss-of-function but not dominantnegative intragenic IKZF1 deletions are associated with an adverse prognosis in adult BCR-ABL-negative acute lymphoblastic leukemia. Haematologica. 2017;102:1739-47.

163. Thottassery JV, Sambandam V, Allan PW, Maddry JA, Maxuitenko YY, Tiwari K, Hollingshead M, Parker WB. Novel DNA methyltransferase-1 (DNMT1) depleting anticancer nucleosides, 4'-thio-2'-deoxycytidine and 5-aza-4'-thio2'-deoxycytidine. Cancer Chemother Pharmacol. 2014;74:291-302.

164. Stewart D, Donehower RC, Eisenhauer E, Wainman N, Shah A, Bonfils C, MacLeod A, Besterman J, Reid G. A phase I pharmacokinetic and pharmacodynamic study of the DNA methyltransferase 1 inhibitor MG98 administered twice weekly. Ann Oncol. 2003;14:766-74.

165. Buggy JJ, Cao ZA, Bass KE, Verner E, Balasubramanian S, Liu L, Schultz BE, Young PR, Dalrymple SA. CRA-024781: a novel synthetic inhibitor of histone deacetylase enzymes with antitumor activity in vitro and in vivo. Mol Cancer Ther. 2006;5:1309-17.

166. Lopez G, Liu J, Ren W, Wei W, Wang S, Lahat G, Zhu Q-S, Bornmann WG, McConkey DJ, Pollock RE. Combining PCl-24781, a novel histone deacetylase inhibitor, with chemotherapy for the treatment of soft tissue sarcoma. Clin Cancer Res. 2009;15:3472-83.

167. Lai C-J, Bao R, Tao X, Wang J, Atoyan R, Qu H, Wang D-G, Yin L, Samson M, Forrester J. CUDC-101, a multitargeted inhibitor of histone deacetylase, epidermal growth factor receptor, and human epidermal growth factor receptor 2, exerts potent anticancer activity. Cancer Res. 2010;70:3647-56.

168. Giaccone G, Rajan A, Berman A, Kelly RJ, Szabo E, Lopez-Chavez A, Trepel J, Lee M-J, Cao L, Espinoza-Delgado I. Phase II study of belinostat in patients with recurrent or refractory advanced thymic epithelial tumors. J Clin Oncol. 2011:29:2052.

169. Yardley DA, Ismail-Khan RR, Melichar B, Lichinitser M, Munster PN, Klein PM, Cruickshank S, Miller KD, Lee MJ, Trepel JB. Randomized phase II, doubleblind, placebo-controlled study of exemestane with or without entinostat in postmenopausal women with locally recurrent or metastatic estrogen receptor-positive breast cancer progressing on treatment with a nonsteroidal aromatase inhibitor. J Clin Oncol. 2013;31:2128.

170. Hainsworth JD, Infante JR, Spigel DR, Arrowsmith ER, Boccia RV, Burris HA. A phase II trial of panobinostat, a histone deacetylase inhibitor, in the treatment of patients with refractory metastatic renal cell carcinoma. Cancer Investig. 2011;29:451-5.

171. San-Miguel JF, Einsele H, Moreau P. The role of panobinostat plus bortezomib and dexamethasone in treating relapsed or relapsed and refractory multiple myeloma: a European perspective. Adv Ther. 2016;33:1896-920.

172. Quintás-Cardama A, Kantarjian H, Estrov Z, Borthakur G, Cortes J, Verstovsek S. Therapy with the histone deacetylase inhibitor pracinostat for patients with myelofibrosis. Leuk Res. 2012;36:1124-7.

173. Raffoux E, Cras A, Recher C, Boëlle P-Y, de Labarthe A, Turlure P, Marolleau J-P, Reman O, Gardin C, Victor M. Phase 2 clinical trial of 5-azacitidine, valproic acid, and all-trans retinoic acid in patients with high-risk acute myeloid leukemia or myelodysplastic syndrome. Oncotarget. 2010;1:34.

174. Kim YH, Bagot M, Pinter-Brown L, Rook AH, Porcu P, Horwitz SM, Whittaker $S$, Tokura Y, Vermeer M, Zinzani PL. Mogamulizumab versus vorinostat in previously treated cutaneous T-cell lymphoma (MAVORIC): an international, open-label, randomised, controlled phase 3 trial. Lancet Oncol. 2018;19: 1192-204.

175. Berthon C, Raffoux E, Thomas X, Vey N, Gomez-Roca C, Yee K, Taussig DC, Rezai K, Roumier C, Herait P. Bromodomain inhibitor OTX015 in patients with acute leukaemia: a dose-escalation, phase 1 study. Lancet Haematol. 2016;3:e186-95.

176. van Zandwijk N, Pavlakis N, Kao SC, Linton A, Boyer MJ, Clarke S, Huynh Y, Chrzanowska A, Fulham M, Bailey DL. Safety and activity of microRNA-loaded 
minicells in patients with recurrent malignant pleural mesothelioma: a first-in-man, phase 1, open-label, dose-escalation study. Lancet Oncol. 2017;18:1386-96.

177. Ottosen S, Parsley TB, Yang L, Zeh K, van Doorn L-J, van der Veer E, Raney AK, Hodges MR, Patick AK. In vitro antiviral activity and preclinical and clinical resistance profile of miravirsen, a novel anti-hepatitis $C$ virus therapeutic targeting the human factor miR-122. Antimicrob Agents Chemother. 2015;59:599-608

\section{Publisher's Note}

Springer Nature remains neutral with regard to jurisdictional claims in published maps and institutional affiliations.

Ready to submit your research? Choose BMC and benefit from:

- fast, convenient online submission

- thorough peer review by experienced researchers in your field

- rapid publication on acceptance

- support for research data, including large and complex data types

- gold Open Access which fosters wider collaboration and increased citations

- maximum visibility for your research: over $100 \mathrm{M}$ website views per year

At BMC, research is always in progress.

Learn more biomedcentral.com/submissions 